\title{
Resolving DNA Damage: Epigenetic Regulation of DNA Repair
}

\author{
Panagiotis Karakaidos ${ }^{1}$ (D), Dimitris Karagiannis ${ }^{2}$ and Theodoros Rampias ${ }^{1, *(1)}$ \\ 1 Biomedical Research Foundation of the Academy of Athens, 11527 Athens, Greece; pkarak@bioacademy.gr \\ 2 Department of Genetics and Development, Columbia University Medical Center, New York, NY 10032, USA; \\ dk3039@cumc.columbia.com \\ * Correspondence: trampias@bioacademy.gr; Tel.: +30-210-659-7469
}

Academic Editors: Daniel Roca-Sanjuán, Virginie L. Lhiaubet-Vallet and Iñaki Tuñón Received: 29 April 2020; Accepted: 25 May 2020; Published: 27 May 2020

\begin{abstract}
Epigenetic research has rapidly evolved into a dynamic field of genome biology. Chromatin regulation has been proved to be an essential aspect for all genomic processes, including DNA repair. Chromatin structure is modified by enzymes and factors that deposit, erase, and interact with epigenetic marks such as DNA and histone modifications, as well as by complexes that remodel nucleosomes. In this review we discuss recent advances on how the chromatin state is modulated during this multi-step process of damage recognition, signaling, and repair. Moreover, we examine how chromatin is regulated when different pathways of DNA repair are utilized. Furthermore, we review additional modes of regulation of DNA repair, such as through the role of global and localized chromatin states in maintaining expression of DNA repair genes, as well as through the activity of epigenetic enzymes on non-nucleosome substrates. Finally, we discuss current and future applications of the mechanistic interplays between chromatin regulation and DNA repair in the context cancer treatment.
\end{abstract}

Keywords: DNA damage; DNA repair; epigenomics; chromatin remodeling

\section{Introduction}

The concept of epigenetics has significantly evolved since it was introduced more than 70 years ago when the embryologist Conrad Waddington introduced the term in order to explain how genotypes give rise to phenotypes during development [1]. Epigenetics is a very extensive field and despite how much this area has evolved, the definition of epigenetics is still under intense discussion as investigators ascribe different definitions to the term. On the mid 1990s, the discovery of DNA methylation as a mechanism for gene expression silencing and the identification of imprinted genes, provided a direct link between mitotically or meiotically heritable changes in gene function [2]. In this direction, Arthur Riggs and colleagues defined epigenetics as "the study of mitotically and/or meiotically heritable changes in gene function that cannot be explained by changes in DNA sequence.

The elucidation of nucleosome structure and recent advances on chromatin biology along with research on posttranslational histone modifications, eventually led to broader definitions of epigenomics in order to include gene activity states that can also be transient or occur in non-dividing cells and therefore are not mitotically inherited [3]. Recently, it was proposed that epigenetics could be considered as the study of both transient and inheritable gene expression changes that are unrelated to DNA sequence changes. Moreover, the term "memigenetics" was introduced to specifically describe inherited chromatin activity states [4]. According to this concept, epigenetic regulation includes chromatin modifications (DNA methylation, histone modifications), nucleosome remodeling, alteration of chromatin architecture, expression of non-coding RNAs, and the network of chromatin-modifying and -binding factors that drive or regulate these changes. Some epigenetic signatures and associated 
transcriptional states such as DNA methylation are stably inherited across many cell divisions and/or generations, while others are transient and can be erased or reversed. In this manuscript we provide insights into the epigenetic processes that participate in transcription and affect the expression of DNA repair components and into the epigenetic processes that are restricted to structural functions and mediate the recognition of DNA damage by DNA repair factors, the accessibility of repair complexes to the sites of damage, the choice of DNA repair pathway and finally, the fidelity of repair process.

Methylation of cytosine residues of CpG dinucleotides on DNA is one of the best characterized epigenetic modifications. This modification plays a critical role in the formation and maintenance of heterochromatin, while its presence in promoter regions with high CpG content correlates with transcriptional repression [5]. A large number of covalent modifications to histone proteins (methylation, phosphorylation, and acetylation) have been described to either promote an open chromatin state that facilitates transcription or a more condensed state that facilitates heterochromatin formation and gene silencing [6]. Chromatin remodeling includes alterations in nucleosome positioning driven by ATP-dependent chromatin remodeling complexes [7] as well as incorporation of histone variants such as H3.3 and H2A.Z that promote specific epigenetic states and play crucial roles in chromosome segregation, transcriptional regulation, and DNA repair [8]. Covalent modifications, nucleosome remodeling, and histone variants function together in order to regulate chromatin processes that require dynamic alteration of DNA structure such as transcription, repair, and replication. Notably, chromatin regulating enzymes have been shown to modify non-histone substrates as well, resulting in regulation of cellular processes such as cell cycle control, differentiation, growth, metabolism, apoptosis, and senescence. In this review we discuss the extended interplay between chromatin regulation and DNA repair, as well as current efforts to apply this knowledge in the clinic.

Large-scale cancer mutation mapping and identification by next generation sequencing in the past few years revealed high frequency of mutations in genes that regulate epigenetic modifications in DNA and histones or chromatin-remodeling processes [9]. These mutations were found to affect chromatin regulator enzymes that catalyze modifications (writers), enzymes that modify or revert the modification (editors/erasers), and enzymes that interact with epigenetic modifications (readers). This type of epigenome deregulations in cancer lead to genome-wide changes in DNA methylation, nucleosome positions, and histone modifications which in turn, affect the local and global chromatin architecture as well as gene expression [10-12]. These changes can affect the efficiency of DNA damage response (DDR) and repair and can allow damage to accumulate at much higher rate leading to genomic instability, which is recognized as hallmark of cancer progression [13].

\section{Types of DNA Damage and DNA Damage Response}

\subsection{Sources of DNA Damage}

Cellular DNA is constantly being damaged by harmful chemical modifications driven by oxidation, alkylation, free radicals, ultraviolet and ionizing radiation. Oxidative stress generated by endogenous metabolic processes generates 8-oxo purine monomers such as the 7,8-dihydro-8oxoguanine (8-oxoG) and other types of oxidized base lesions such as the 8-hydroxy-2-deoxyguanosine $(\mathrm{OHdG})$, and 5-hydroxyuracil. The accumulation of 8-oxoG and OHdG lesions has a severe mutagenic effect because these bases mismatch with adenine during DNA replication [14]. Damaging chemical modifications on DNA can also lead to replication fork stalling during the S-phase of cell cycle and further increase DNA damage [15]. Other types of DNA damage include single stand DNA breaks (SSBs), double strand DNA breaks (DSBs), adducts, intrastrand and interstrand cross-links, and insertion/deletion mismatches. Ionizing radiation (IR) and ultra violet (UV) light represent exogenous sources of DNA damage. Ionizing radiation produce a wide variety of DNA lesions. Among them, DSBs are considered the most cytotoxic and deleterious ones for genomic integrity since, if they are improperly repaired, they can lead to loss of genetic material, chromosomal duplications or translocations, and carcinogenesis [16]. The predominant UV light induced chemical DNA alteration is 
dimerization of adjacent pyrimidine bases (usually thymine bases) leading to cyclobutane dimers [17]. Other environmental agents that induce DNA damage are alkylating and crosslinking agents [18].

Deregulated origin firing or licensing during DNA replication can also lead to DNA damage. Collision of replication forks has been shown to cause severe lesions, including DSBs and re-replication of DNA [19]. Entering $S$ phase with a reduced number of active origins is associated with long replication tracks and replication fork stalling as well as incomplete replication and chromosome breakages during mitosis [20]. On the other hand, uncontrolled origin activity and increased origin firing can exhaust deoxynucleoside triphosphates (dNTPs) and replication protein A (RPA) levels, causing replication fork collapse and DNA damage [21]. Dysfunctional origin activity and replication stress is induced by oncogene activity and is considered a hallmark of cancer [22].

\subsection{DNA Repair Is a Multi-Step Process}

DNA repair, cell cycle checkpoints, and cell death pathways collectively respond to DNA damage in order to reduce its deleterious consequences to genomic integrity. The DNA repair machinery includes a complex network of sensors, transducers, and effectors that coordinate the repair of DNA damage and ensures DNA replication fidelity. Sensor proteins recognize alterations on the DNA structure such as nicks, gaps, DSBs, and replication lesions. Signal transducers are enzymes that initiate signaling cascades to adjacent nucleoprotein complexes promoting the activation of the cell cycle checkpoints and DNA repair pathways. Effectors repair the DNA damage and inhibit cell cycle progression. In mammalian cells, at least nine distinct pathways are involved for the repair of different genotoxic lesions: mismatch repair (MMR), base excision repair (BER), nucleotide excision repair (NER), translesion synthesis (TLS), homologous recombination (HR), non-homologous end joining (NHEJ), alternative end joining (alt-EJ), Fanconi anemia (FA), and O6-methylguanine DNA methyltransferase (MGMT). Despite the fact that these pathways repair different types of lesions in distinct cell cycle phases, they form a precisely regulated network of multifunctional DNA repair hubs. DSBs are mainly repaired through NHEJ and HR. Whereas NHEJ simply ligates the double helix with no or minimal processing, HR requires the formation of a $3^{\prime}$ ssDNA through the processing of DSB ends by specific nucleases and relies on the recognition and pairing of this $3^{\prime}$ ssDNA tails with an intact homologous sequence [23].

\subsection{DDR Initiation Requires Recruitment of Sensor Proteins to Damaged Chromatin}

A key element of DDR is early detection of damaged DNA, followed by recruitment of specific DNA repair complexes to the damaged sites that initiate the repair signaling. After DNA damage, sensor proteins such as PARP1 or H2AX, and complexes, including the Ku70/80 and MRN (MRE11/RAD50/NBS1) directly recognize the structure of DSBs and SSBs and recruit ATM, ATR, and DNA-PK proteins at the break sites. PARP-1 has long been demonstrated as an important first-line sensor of SSBs [24]. Recent structural studies have shown that two flexibly linked N-terminal zinc finger structural elements of this protein, recognize the extreme deformability of SSBs and induce allosterically the activation of the C-terminal catalytic domain [25]. On the other hand, MRN and Ku70/80 complexes are considered as major sensors for DSBs. MRN complex has the ability to bind free DNA ends by one-dimensional sliding. Dynamic DNA binding within the Rad50 domain allows MRN to slide through homoduplex DNA, whereas DNA end recognition is catalyzed by the Mre11 subunit. In contrast, $\mathrm{Ku}$ recognizes free DNA ends exclusively via direct binding [26]. PARP1 catalyzes the formation of linear chains of ADP-ribose residues (PAR chains) that form a platform to recruit DNA repair proteins via their PAR-binding domains at the sites of DNA damage [27,28]. Like PARP1, the Ku complex, consisting of Ku70 and Ku80 subunits, functions as a damage sensor, but promotes DNA repair through a different pathway. Binding of the Ku complex to DSBs recruits and activates the DNA-PK catalytic subunit, which promotes NHEJ [29], contrary to PARP1 that promotes alt-EJ [30]. Thus, the antagonism between PARP1 and the Ku complex at DSBs may play an important role in determining repair choices. In addition to PARP1 and Ku proteins, the MRN complex, acting as a 
DNA sensor protein, can prime the activation of DNA repair cascades via recruitment of ATM to the region near DNA lesions [31]. ATM is the main kinase responsible for the phosphorylation of H2AX, which is one of the earliest steps for the recruitment of additional DDR factors [32,33]. DNA repair pathways are highly linked, and depend on the cellular pathways that modulate locally the chromatin structure at damaged sites in order to ensure accessibility of damage sensors, signal transducers and repair proteins.

Mispaired bases that arise from polymerase misincorporation errors, destabilize the DNA duplex forming a flexible kink on the DNA structure that is recognized by MutS complex in mismatch repair (MMR). This recognition results in the formation of a stable ATP-bound MutS sliding clamp that encircles the DNA double helix and can efficiently diffuse along the DNA backbone. The MutS sliding clamp then recruit MutL onto the mismatched DNA, forming a MutS-MutL complex for the efficient repair [34].

In mammalian nucleotide excision repair (NER), a wide variety of DNA lesions such as ultraviolet light (UV)-induced pyrimidine dimers, as well as intra-strand crosslinks and bulky adducts that are induced by electrophilic chemicals, are recognized by the XPC-RAD23B repair complex. The local thermodynamic destabilization and structural distortion of the double helix by loss of Watson-Crick base pairing, is ubiquitous across diverse NER lesions and provide the basis for their recognition by XPC-RAD23B. Recent studies have demonstrated that this complex discriminates between damaged and non-damaged sites by sensing differences in local deformability on the undamaged strand of the lesion [35,36]. Moreover, the crystal structure of Rad4, the yeast XPC orthologue, bound to DNA containing pyrimidine dimers, revealed that Rad4 recognizes lesions that locally destabilize the Watson-Crick double helix in a manner that permits the insertion of the $\operatorname{Rad} 4$ b-hairpin through the DNA duplex and the flipping-out of the two damaged base pairs [37].

The base excision repair (BER) machinery is specialized to fix single base damage in the form of small chemical modifications such as oxidation, alkylation, and deamination that do not usually cause DNA helix distortions. For instance, 8-oxoG is very stable when paired with cytosine in duplex DNA, and the 8-oxoG-containing DNA is not thermodynamically destabilized [38]. DNA glycosylases play a key role in the recognition of such DNA lesions. All glycosylases share a common mode of action for damage recognition; they rotate bases out of the DNA helix into a catalytic pocket, the architecture of which permits a sensitive detection of altered chemical base structure. If the damaged base fits to active site configuration, cleavage of the glycosidic bond will occur, resulting in the generation of apurinic/apyrimidinic sites. Therefore, the detection process requires the scanning of the chemical surface of single bases across DNA [39]. A schematic representation of the early steps of DNA damage response in MMR, BER, and NER pathways is shown in Figure 1. 

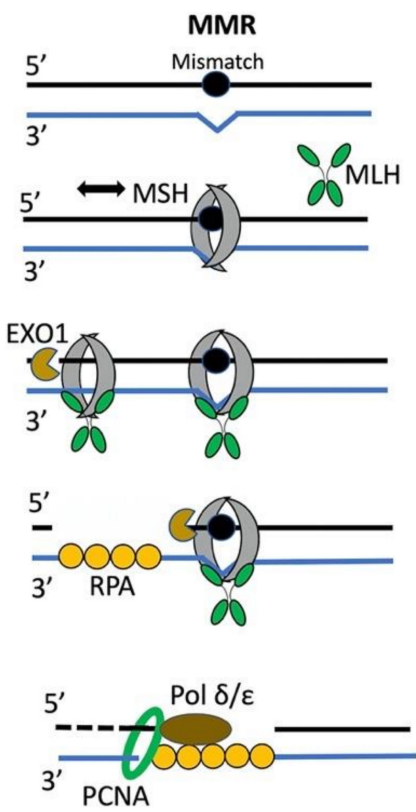
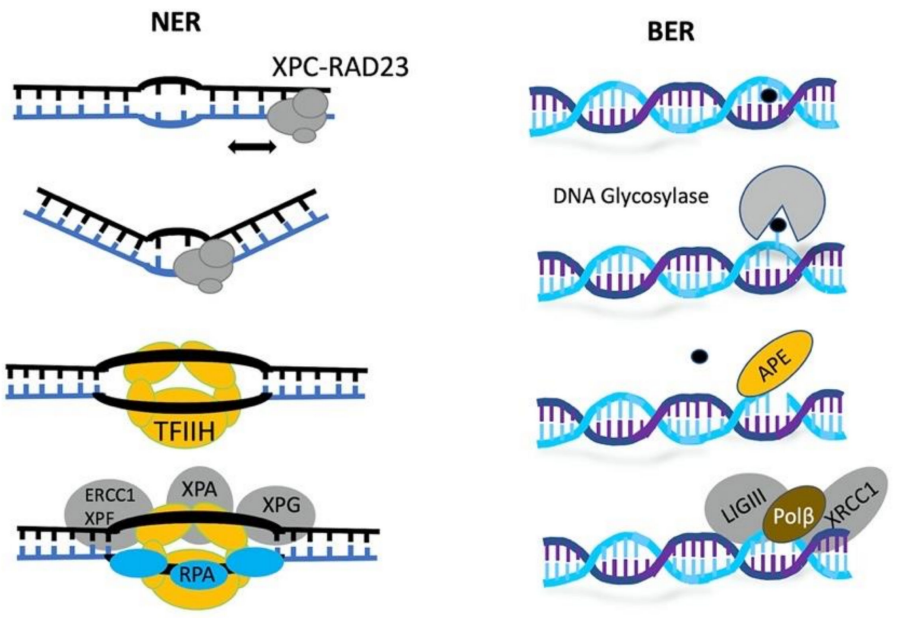

Figure 1. Early steps of DNA damage response that include DNA damage recognition and recruitment of additional repair factors in mismatch repair (MMR), nucleotide excision repair (NER), and base excision repair (BER) pathways.

\section{Chromatin Regulation during DNA Repair}

\subsection{Epigenetic Driven Chromatin Remodeling Is One of the Earliest Responses to DNA Damage}

The first step in DSB repair by HR is the processing of the ends by specific repair nucleases, however, the dense multilevel packing of chromatin poses a challenge for the DNA repair machinery, which requires access to DNA lesions. Early biochemical studies provided evidence that chromatin structure is remodeled in the presence of DSBs and that chromatin is more sensitive to nucleases [40-42]. Recent methodological and technological advancements revealed, also, that long range clustering of DSBs occurs on active genes [43] and suggest that DSB bearing chromatin becomes extensively remodeled within the boundaries of the containing TAD (topologically associated domain), bringing the nucleosomes into spatial proximity to facilitate access of repair factors and $\gamma \mathrm{H} 2 \mathrm{AX}$ spreading [44]. Similarly, UV irradiation was found to induce a relaxation to chromatin within the entire nucleus $[45,46]$.

This damage-induced chromatin remodeling facilitates also the access of repair proteins to DNA lesions. Prior studies using localized laser micro-irradiation and GFP-tagged H2B histone revealed that chromatin is rapidly and locally relaxed following DSB induction by laser micro-irradiation and then enters a re-compaction phase, necessary for full DDR activation $[47,48]$. According to these studies, the initial de-condensation of irradiated chromatin was found to be ATM independent and extremely rapid, occurring within seconds after damage. Notably, de-condensation kinetics were found to be similar to the kinetics of PARP1 driven poly ADP-ribosylation, suggesting that chromatin relaxation is associated with PARP1 activity in early DDR. Indeed, inhibition of PARylation abolished chromatin relaxation at DNA damage sites indicating that chromatin relaxation is PARylation dependent [49].

The recent development of CRISPR/Cas9 tools to induce multiple DSBs at known positions in the genome, combined with ChIP-seq and/or super-resolution microscopy, magnified our potential to study the nature and function of chromatin at DSBs. Work from many laboratories in epigenetics have now revealed that these structural alterations are driven by dynamic changes of chromatin modifications and nucleosome positioning after DNA damage, supporting a model where chromatin unfolding and spatial expansion of chromatin states that occur during DNA damage is mediated by specific epigenetic and chromatin remodeling factors. 
PARylation has been involved in the recruitment and regulation of several chromatin-remodeling enzymes, whose ATP-dependent activity could promote chromatin relaxation. It is considered that the nucleosome remodeler Arc1 (also known as CHD1L), which contains an ADP-ribose-binding domain, induces an initial relaxation phase [49], which in turn promotes the recruitment of additional remodelers such as chromodomain helicase DNA-binding proteins 3/4 (CHD3 and CHD4 respectively) [50,51], SMARCA5 and CHD2 [52,53]. The activity of chromatin remodelers in combination with the addition of a large number of negatively charged PAR chains onto chromatin contribute to the rapid relaxation of the chromatin structure at DNA damage sites.

Besides PARP1 driven ADP-ribosylation of histones, post-translational modifications of histone tails at damage sites also have a crucial role on chromatin remodeling at early stages of DDR. These modifications can modulate inter-nucleosome contacts, altering higher-order chromatin organization or provide binding sites for recruitment of DDR transducers and effectors. Several groups have demonstrated that rapid $\mathrm{H} 4$ acetylation (H4K16ac) is catalyzed on damaged sites and extends for many kilobases away from the break, following the spreading pattern of $\gamma \mathrm{H} 2 \mathrm{AX}$ accumulation [54,55]. The N-terminal tail of histone $\mathrm{H} 4$ interacts with the acidic patch on the surface of H2A-H2B dimers of adjacent nucleosomes. Disruption of this interaction by acetylation of histone $\mathrm{H} 4$ at DSBs promotes chromatin unpacking and formation of open, relaxed, chromatin structures [56]. Acetylation of lysine 16 of histone 4 (H4K16) at DSBs is carried out by the histone acetyltransferase TIP60 and its inactivation is sufficient to block chromatin decompaction during DNA damage [57].

\subsection{Regulation of Chromatin During Repair of DSBs in Heterochromatin}

Nuclear centromeric, pericentromeric regions, telomeres, and repetitive elements comprise the constitutive heterochromatin, while developmentally silenced genes constitute the facultative heterochromatin. Both constitutive and facultative heterochromatins represent highly compacted chromatin, therefore recognition of DNA damage and initiation of early DDRin these regions require a step of chromatin unpacking. Furthermore, the presence of repetitive DNA elements within heterochromatin can initiate aberrant homologous recombination events during repair, such as sister chromatid exchanges or inter-chromosomal recombination, leading to deletions, duplications, translocations, and formation of dicentric or acentric chromosomes. Despite this risk, homologous recombination (HR) is a primary pathway for heterochromatin repair [58]. Thus, chromatin unpacking of heterochromatin during DSB repair should be precisely regulated in order to prevent inappropriate recombination events.

Initiation of HR repair and chromatin unpacking at sites of heterochromatic DSBs requires the phosphorylation of HP1-interacting protein KAP-1 by ATM. This phosphorylation reduces the strength of KAP-1 interaction with damaged heterochromatin, and promotes the release of the chromatin modifier CHD3.1 (CHD3 isoform1). The release of CHD3.1 in turn, drives chromatin relaxation which provides access to DNA repair complexes [59,60].

While the exact molecular mechanism that links damaged DNA sensing and chromatin unpacking at sites of heterochromatic DSBs is unknown, it might involve the histone acetyltransferase activity of Tip60. Upon DNA damage, MRN complex recruits Tip60 at heterochromatic DSBs. This binding is promoted also by the ability of Tip60 to interact with histone H3 trimethylated on lysine 9 (H3K9me3). Tip60-H3K9me3 interaction, activates Tip60's acetyltransferase activity which leads to damage signaling kinase ATM acetylation and activation [61]. ATM activation in turn, promotes KAP-1 phosphorylation and chromatin unpacking as mentioned above.

Notably, recent studies in Drosophila and mouse cells have shown a relocation of heterochromatin DSBs for the completion of HR repair. This relocation ensures safe and precise HR, while preventing aberrant recombination, by isolating the DSBs and their homologous templates away from ectopic sequences before strand invasion [62]. In Drosophila cells, SUMOylation of HR components after resection has a crucial role in this mechanism as it generates a temporary block to Rad51 recruitment inside the heterochromatin domain to prevent ectopic recombination [63]. Subsequently, damaged sites 
relocate to anchoring points at the nuclear periphery, in a process that requires the checkpoint kinase ATR [58] and histone demethylase activity by the lysine demethylase 4A (KDM4A) [64]. In contrast, DSBs in mouse cells relocate to the periphery of heterochromatin domains where they are stabilized by the RAD51/BRCA2 [65].

\subsection{Epigenetic Factors and DNA Repair Choice between HR and NHEJ}

Soon after initiation of DDR, the stage is set for repair of the DSB by competing factors that promote NHEJ or HR repair, and less frequently alt-EJ. More specifically, factors compete for initiation of DNA end resection, the first step of the HR repair pathway. The chromatin landscape has been shown to influence this competition depending on its structure and histone marks that are present. For example, SWI/SNF and Ino80 complexes have been shown to compete for chromatin remodeling and levels of H2A.Z exchange, the latter of which promotes HR repair by H2A.Z eviction, DNA end-resection, and presynaptic filament formation [66-68]. Moreover, histone marks associated with open chromatin such as $\mathrm{H} 4$ acetylation and H3K36me3 have also been associated with HR repair, since chromatin relaxation favors end-resection $[69,70]$. Conversely, in regions of heterochromatin, NHEJ is favored because of compact chromatin and repetitive elements which hinder HR [65]. Importantly, there is also spatial distinction between HR repair and NHEJ in the nucleus, since when HR takes place in heterochromatin regions the DSB site is extruded as described previously [58]. Finally, demethylation of histone 4 at lysine 20 (H4K20me2) promotes NHEJ by 53BP1 recruitment, reportedly as a way to ensure utilization of this pathway in pre-replicative chromatin [71-73]. These interactions have important implications in contexts where the choice of DNA repair pathways is critical, such as cancer treatment.

\subsection{Epigenetic Regulation of Mismatch Repair}

Mismatch repair is required for the detection and correction of single-nucleotide mismatches that might escape proofreading during replication. In addition, MMR is essential for correcting small insertions and deletions that are generated when replication complexes move across repetitive sequences (microsatellites). The MMR process includes recognition of the mispairing, followed by DNA endonuclease nicking of the daughter strand, excision of the daughter strand, and gap-filling by a DNA polymerase. Recognition of replication errors by MMR is mediated by MSH2/MSH6 (MutS $\alpha$ ) and MSH2/MSH3 (MutS $\beta$ ) heterodimers [74]. Binding of MutS complexes to the DNA lesion facilitates the recruitment of the MutL complex (heterodimer MLH1/PMS2) which initiates DNA repair by a single-stranded nick [75]. Other components of the MMR machinery include the exonuclease1 (EXO1) and polymerases with proofreading activity, such as polymerase $\varepsilon$ and $\delta$ (POLE and POLD). Loss of MMR activity due to mutational inactivation or transcriptional silencing of any of its key players is associated with tumor development and microsatellite instability (MSI). At the genomic level, MMR-deficient tumors (MMRd) are characterized by a hypermutator-phenotype and accumulate large numbers of small insertions and deletions (indels). MMRd tumors represent approximately $20 \%$ of human cancers but are unequally clustered across different tumor types. High prevalence is observed in endometrial $(\sim 30 \%)$, gastric $(\sim 20 \%)$, and colorectal cancers $(\sim 15 \%)$, while the proportion of MMR in other tumor types is lower.

There is increasing evidence that epigenetic and remodeling factors play a crucial role in efficient MMR activity. The epigenetic histone mark H3K36me3 seems to be important for recruitment of MMR complexes during DNA replication [76]. Functional experiments have demonstrated that human Msh6 protein harbors a PWWP motif that mediates binding to the H3K36me histone mark during the S-phase of the cell cycle [77]. Moreover, cells lacking the H3K36 tri-methyltransferase SETD2 display characteristics of MMR-deficient cells such as microsatellite instability and high mutation burden [78]. Recent studies have also revealed that SMARCAD1, an SNF-2 family nucleosome remodeler with ATPase activity is an important MMR factor that facilitates nucleosome exclusion from post-replication regions with mismatch base pair. SMARCAD1 interacts with Msh2 protein and facilitates the excision step in EXO1-dependent MMR [79]. 
Although MMR deficiency has been studied for decades, large amounts of exome sequencing data, now available from The Cancer Genome Atlas (TCGA), revealed that MMRd tumors exhibit a high frequency of frameshift mutations in important chromatin remodelers and histone modifiers genes such as ARID1A, ARID1B, ARID2, ARID4A, EP300, CREBBP, KMT2C, and KMT2D suggesting that MMRd tumorigenesis is associated with epigenetic deregulation [80].

\subsection{The Role of Chromatin Remodelers in BER and NER}

In eukaryotes, base excision repair (BER) is the major pathway for the repair of DNA alkylation and oxidation. Chemically damaged nucleotides, such as lesions of 8-oxoguanine (8-oxoG), activate the BER pathway. Initially, a glycosylase, cleaves the glycosidic bond that links the lesion to the sugar-phosphate backbone and generates an abasic site. Eleven glycosylases have been identified so far in humans and are categorized based on their structure [81]. Subsequently, the apurinic or apyrimidinic sites are bound by the endonuclease APE1, which cleaves the DNA backbone on the 5' side of the abasic deoxyribose phosphate, creating a nick [82]. The polymerase synthesis step of BER employs either repair polymerase Pol $\beta$ which adds a single nucleotide, or one of the processive polymerases Pol $\delta$ or Pol $\varepsilon$, adding up to 13 nucleotides to the $3^{\prime}$ hydroxyl group of the nucleotide $5^{\prime}$ of the nick [83]. The remaining deoxyribose phosphate is removed by the deoxyribophosphate lyase activity (dRPase activity) of Pol $\beta$, whereas the $5^{\prime}$ stretch of nucleotides, when added by Pol $\delta$ or Pol $\varepsilon$, is cleaved by the flap endonuclease FEN-1 [84]. The final step of BER is ligation of the nicked strand by DNA ligase III $\alpha$ in a complex with its partner protein XRCC1. For execution of this multi-step repair process it is necessary that DNA is accessible to the enzymatic activity of all BER components. Numerous studies have demonstrated an inverse correlation between the level of chromatin compaction and BER activity [85]. Several in vitro studies also indicate that chromatin remodeling activity by members of SWI/SNF subfamily and ISW1/ISW2 proteins is sufficient to facilitate the glycosylase APE-1 and the polymerase synthesis step during BER [86-88]. It is considered that chromatin remodelers provide accessibility to BER repair proteins by either remodeling, or combined remodeling and sliding mechanisms.

Nucleotide excision repair (NER) is the major pathway for the repair of bulky DNA lesions caused by UV, environmental mutagens, and cancer chemotherapeutic drugs. Two distinct DNA damage recognition pathways can activate NER. Global genome NER (GG-NER) is activated by helix distortions associated with DNA lesions anywhere in the genome. The main damage sensor in GG-NER is the XPC-RAD23B- CETN2 protein complex. Transcription-coupled NER (TC-NER) is activated by stalled RNA Pol II during transcript elongation by a lesion in the template strand [89]. Similar to the BER pathway, numerous in vitro NER assays have shown that the packed nucleosome structure can be a barrier to efficient NER function. In vitro studies with reconstituted mononucleosomes, purified SWI/SNF complexes were found to increase the accessibility of damaged DNA and stimulate NER repair $[90,91]$. However, it is not clear yet whether SWI/SNF complexes are involved in early NER steps facilitating XPF recruitment and lesion detection, or are recruited by XPF and promote the binding of late NER factors XPG and PCNA. The latter is supported by experiments showing that knockdown of chromatin remodelers BRG1, BRM, and ARID1A/B have no effect on XPC recruitment but can impair the recruitment of late NER factors ERCC1 and XPA [92,93]. Given the broad role of SWI/SNIF complexes in NER and BER repair pathways and the high incidence of mutations in family members across different cancer types, the exploitation of SWI/SNF deficiency induced susceptibilities is crucial for the development of efficient and precise therapies for SWI/SNF-mutated cancers.

Collectively, epigenetic regulation has a crucial role in all major DNA repair pathways. A schematic synopsis of the most common ones is presented in Figure 2. 


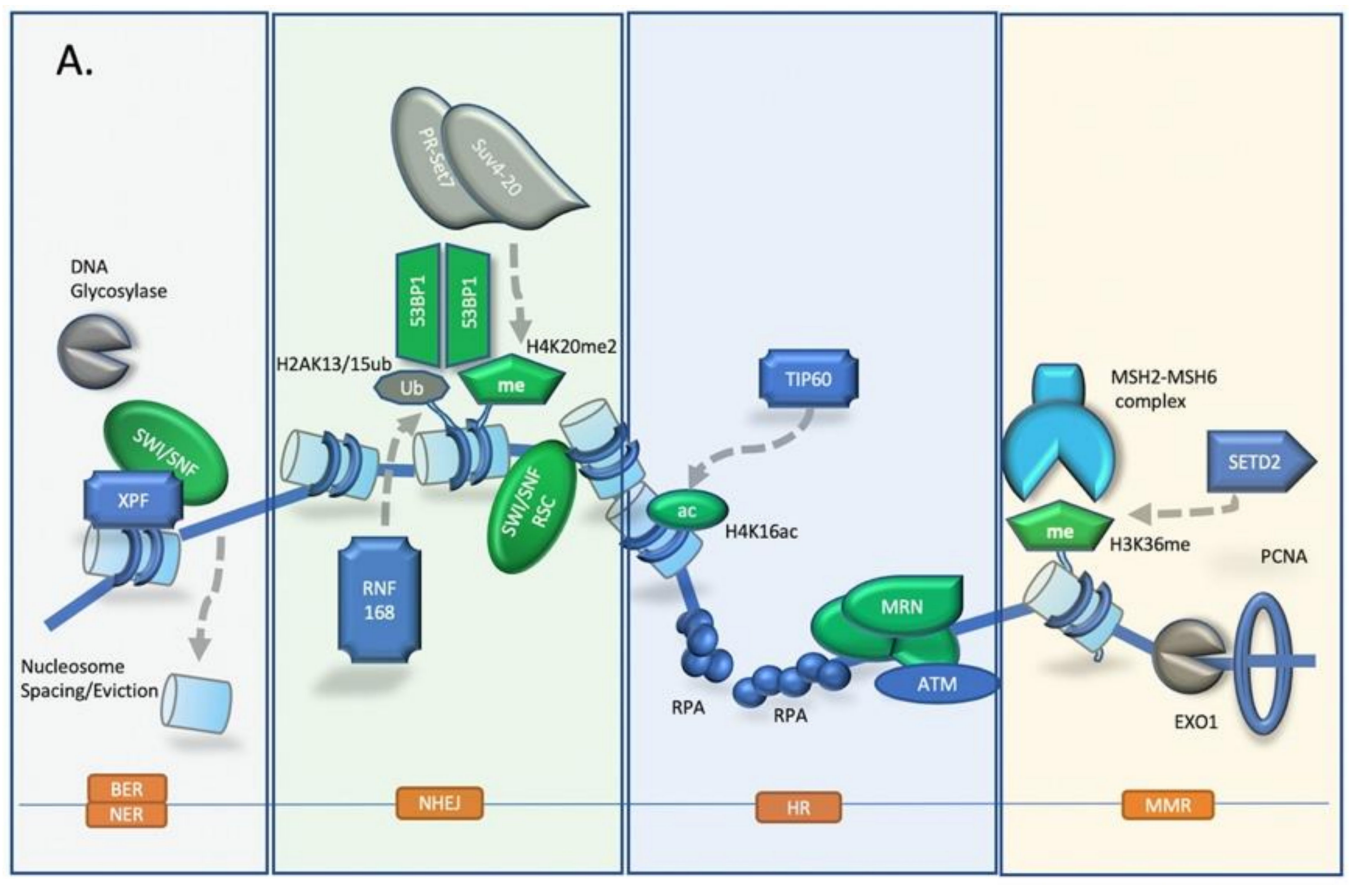

B.

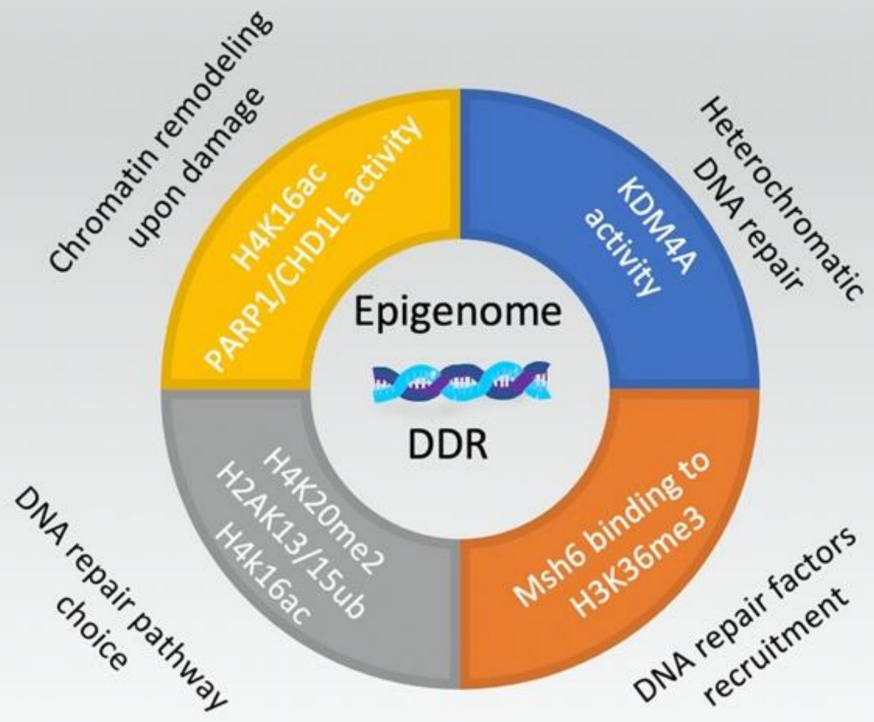

Figure 2. Epigenetic-driven chromatin modifications and DNA repair (A) Epigenetic regulation of key DNA repair processes with emphasis in chromatin modifications. (B) Multilayer epigenetic regulation upon DNA damage response (DDR).

\section{Epigenetic Regulation of DNA Repair Factors Though Transcription}

\subsection{Epigenetic Regulation of DNA Repair Component Expression}

A vital aspect of efficient cellular response to DNA damage is transcriptional regulation of DNA repair proteins and related factors. Gene expression of DNA repair genes is regulated by master transcription factors, as well as by epigenetic mechanisms. Gene expression regulation of DNA repair components has been studied primarily under conditions of genotoxic stress. DNA damage, such as DSBs, triggers the activation of transcription factors such as p53, BRCA1, NF- $\mathrm{kB}$, and AP-1. The tumor 
suppressor protein p53 is stabilized by phosphorylation at multiple sites by multiple DDR kinases, including ATM and CHK1/2 [94,95]. Subsequently, p53 leads to transcriptional activation of multiple DNA repair genes of NER, BER, MMR, and NEHJ pathways [96-99]. Another target of ATM and ATR is BRCA1 [100], which when phosphorylated has been shown to promote transcriptional activation of DNA repair genes [101] by forming transcriptional complexes with multiple partners, including p53 [102]. Furthermore, the NF- $\mathrm{kB}$ transcription factor is activated during genotoxic stress through the ATM/NEMO axis [103], and has been reported to drive transcription of the DNA repair proteins BRCA2, REV3, and MGMT [104-106]. Lastly, a major output of DDR is activation of the MAPK pathway [107]. MAPK signaling leads to the activation of AP-1, which regulates the expression of many DNA repair proteins, including BER, NER, and MMR genes [108-112]. Importantly, all the above-mentioned master transcription factors drive broad transcriptional programs with significant cross-talk, which facilitates induction of a robust cellular response to DNA damage.

A central aspect of basal transcriptional regulation of DNA repair genes is the epigenetic state of the locus. Repressive chromatin marks, such as DNA methylation, have been associated with reduced gene expression and defective DNA repair in a number of genes. For instance, somatic biallelic methylation of the MLH1 promoter is an important mechanism that leads to MLH1 silencing and mismatch repair deficiency in colorectal cancer [113] and endometrial cancer [114]. Associations between MLH1, MSH2 promoter methylation and mismatch repair deficiency in other tumor types have also been reported [115-117]. An H3K4me1 enriched enhancer region located $35 \mathrm{~kb}$ upstream of the MLH1 transcriptional start site (TSS) has also been implicated in positive regulation of MLH1 expression. Functional studies revealed that CTCF binding and H3K4me1 within this enhancer is critical for enhancer function and MLH1 expression [118].

BRCA1 promoter methylation is also a frequent event in cancer, that is associated with reduced mRNA and protein levels and HR deficiency [119,120]. Methylation of ERCC1, a component of NER, was correlated with reduced expression and chemosensitivity in glioma [121]. Such changes in chromatin state are often stochastic events confined to a genomic locus, and are sustained because they confer advantages in tumor progression, such as genomic instability [13]. We and others have shown that global epigenetic changes in cancer cells can also affect DNA repair through loss of gene expression of essential DNA repair genes. For instance, KMT2C inactivation in solid tumors leads to HR deficiency through loss of KMT2C binding and activating histone modifications in promoters of ATM and BRCA1 genes, leading to reduced expression levels [122]. In the context of cancer treatment, EZH2 overexpression was reported to lead to DNA damage sensitivity through silencing of RAD51 paralog proteins [123], while inhibition of HDAC enzymes has been shown to downregulate HR repair components and sensitize tumors to chemotherapy [124].

\subsection{Epi-miRs on the Epigenetic Regulation of DDR Components Transcription}

It is increasingly clear that the complexity of gene expression regulation is decisively aided by an additional level of control, the one imposed by microRNAs (miRs). More than 1000 miRs regulate the expression of $>60 \%$ of all human proteins [125]. However, in the past decade, bidirectional interplay between miRs and epigenetics has become evident [126-128]. In other words, epigenetic modifications regulate the expression of numerous miRs but, also, several miRs, known as Epi-miRs, regulate, directly or indirectly, the expression of various epigenetic enzymes (mainly DNMTs, HDACs and KDMs). Herein we will focus on the role of Epi-miRs on the epigenetic control of DDR.

Epi-miRs comprise a small fraction $(5-10 \%)$ of total miRs $[127,128]$. Of those, mir-29, the first Epi-miR to be discovered, which is known to repress DNMT3A, DNMT3B, and DNMT1 expression, was found to be upregulated upon DNA damage in a p53-dependent manner $[129,130]$. Oxidative stress also leads to acute accumulation of mir-29 through TGF- $\beta$, followed by suppression of Suv4-20h, reduced H4K20me3, DNA repair deficiency, and genomic instability [131]. Moreover, the association between mir-29, expression of DNMT3A, global DNA methylation and DNA damage levels upon irradiation was also confirmed on several mouse brain tissues [132]. In a similar manner, miR-140, 
through its control over HDAC4 and HDAC7, was shown to participate in the DDR upon exposure to various DNA damaging agents in several tissues [133-135].

Similarly, the miR-99 family (miR-99a, $-99 \mathrm{~b}$, and -100) modulate DDR through suppression of the SWI/SNF chromatin remodeling factor SNF2H/SMARCA5, a component of the ACF1 complex, leading to reduced BRCA1 localization onto damaged sites and reduced rate and overall efficiency of HR and NHEJ repair pathways [136]. Epi-miR's involvement in the epigenetic regulation of DDR and repair, couples and extends the known strong effect of other miRs on these processes. Collectively, these findings open a new fascinating area of research that can contribute to the efforts to elucidate the highly complex regulatory networks during DDR.

\section{Nucleosome-Independent Regulation of DDR by Epigenetic Factors}

The contribution of epigenetic factors on DDR regulation is not restricted to histone modifications but is now evident through their interaction with numerous non-histone substrates. The prominent role of post translational modifications (PTMs), like phosphorylation and ubiquitination, in DDR and repair processes is well established and extensively reviewed. However, less common modifications like methylation on lysine and arginine residues, imposed by epigenetic enzymes on non-histone proteins, is an emerging field where a new level of regulation in key DDR processes becomes unraveled. Herein we will focus on the contribution of lysine and arginine methylation of non-histone proteins by epigenetic enzymes in DNA damage-related processes (Figure 3).

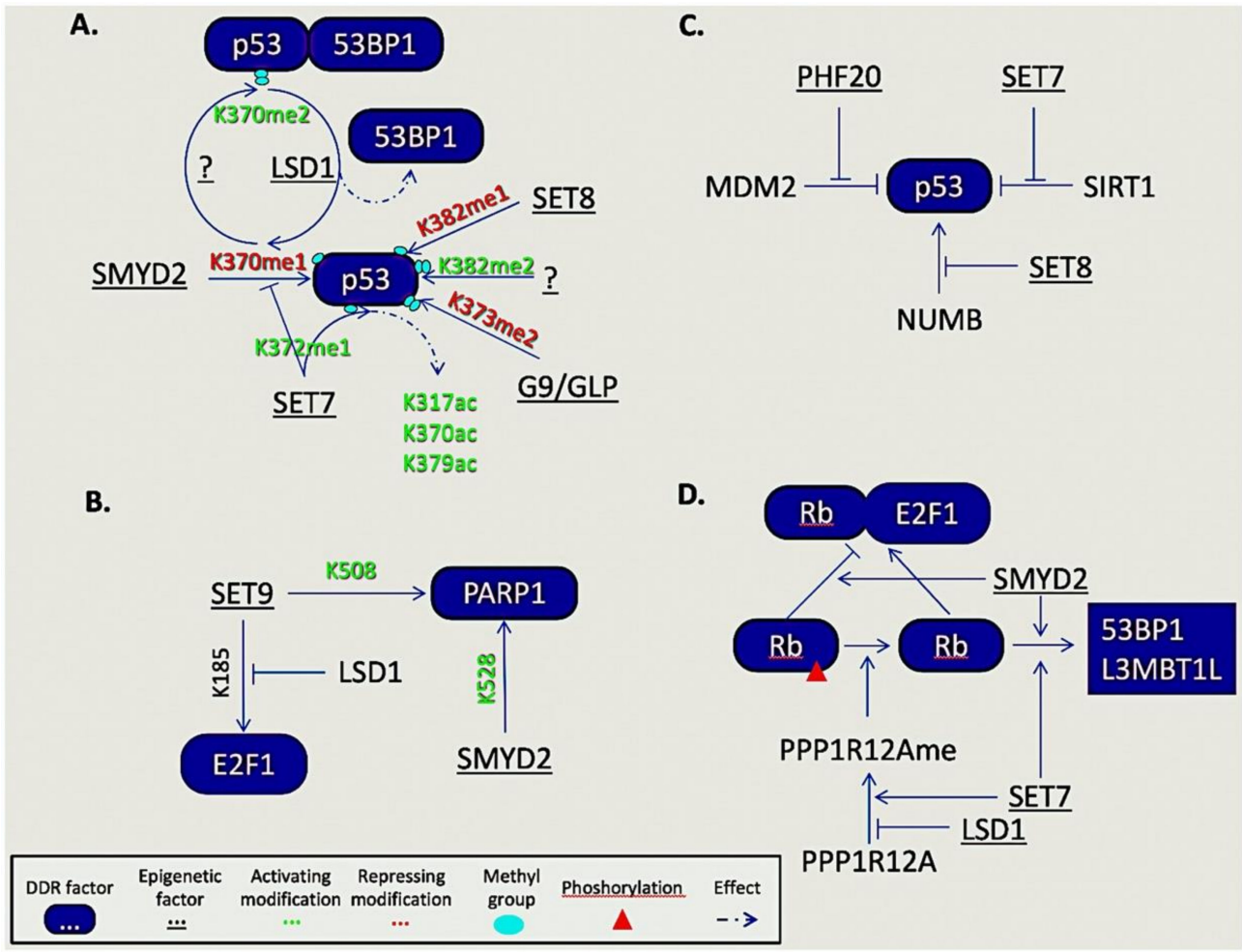

Figure 3. Regulation of key non-histone DDR components by epigenetic factors. (A) Direct lysine methylation of p53. (B) Indirect regulation of p53 through methylation by epigenetic factors. (C) Examples of non-histone epigenetic regulation of DDR components. Of note the opposing roles of SET9 and LSD1 on E2F1 methylation. (D) Regulation of Rb-E2F1 axis by epigenetic factors.

\subsection{Non-Histone Lysine Methylation}

It is increasingly evident that lysine methylation on DDR proteins influences, positively or negatively, their chromatin binding, enzymatic activity, subcellular localization, and their protein interactions [137-139]. The most prominent example of such proteins is p53, a key regulator of 
numerous cellular processes including DNA damage response and repair. Up to date, four lysine residues, K370, K372, K373, and K382, of p53 have been found mono- or di-methylated [140-143]. Of these, K370me1, K373me2, and K382me1 by SMYD2, G9a/GLP, and SET8, respectively, have been reported to repress p53 activity. On the contrary, di-methylation of K370 and K382, by unknown so far lysine methyltransferases, promote $\mathrm{p} 53$ function facilitating its binding with 53BP1 and PHF20, as well as p53's recruitment on the promoter of p21 upon DNA damage [141,142,144]. However, the interplay of lysine methylation marks is dynamic. LSD1, the first lysine demethylase (KDM) to be discovered [145], was shown to demethylate K370me2 to the mono-methylation state with subsequent blockade of the p53-53BP1 interaction [144]. Moreover, the presence of K372me1 (catalyzed by SET7) was shown to promote the nuclear localization, stability, and transcriptional activity of p53, as well as to disrupt its interaction with SMYD2. Another report suggested that SET7 ablation in mouse embryonic fibroblasts prevented the p53-TIP60 interaction leading to decreased acetylation of p53 at K317, K370, and K379, underscoring the interplay between PMTs on p53 regulation [146].

Besides p53, the E2F-1 transcription factor is also methylated during DDR. E2F-1 plays a central role in the DNA damage-induced cell death and, in cells lacking p53, its K185 methylation by SET9 suppresses E2F-1 accumulation, thus, impairing its apoptotic function [147]. Interestingly, LSD1 is able to reverse this mark, indicating that cell fate decisions upon DNA damage are further controlled by methylation.

Another complex protein-protein interplay that is controlled through phosphorylation and methylation events that affect processes like cell cycle progression and DDR was evident in the tumor suppressor retinoblastoma (RB) protein. Upon RB phosphorylation, E2F-1 is released and promotes cell cycle progression. Methylation of RB by SMYD2 enhanced its phosphorylation and E2F-1 mediated cell cycle progression [148]. In addition, RB could be dephosphorylated by PPP1R12A when mono-methylated at K442 by SET7 [149]. However, the same report showed that LSD1 could remove this methylation mark, rendering PPP1R12A susceptible to ubiquitination and proteasomal degradation.

Recently, in a large screen for SET7 methylation targets related to DDR, Thandapani et al. identified FEN1 as one. FEN1 was found monomethylated at K377 by SET7 throughout cell cycle. They reported that this mark did not affect the endonuclease activity of FEN1 but it was required for the cellular response to replicative stress [150]. Another target of SET7 is ubiquitin-like with PHD and RING finger domains 1 (UHRF1). UHRF1 methylation at K385 facilitates its interaction with PCNA leading to PCNA polyubiquitination, a necessary event for the initiation of HR repair pathway [151]. Once again, LSD1 is the enzyme that can erase SET7's mark.

At the onset of DDR, numerous DDR factors become PARylated by PARP1. However, PAR formation and PARP1 recruitment at DNA damage sites following IR is controlled by SET7/9 and SMYD2 through K508 and K528 methylation of PARP1, respectively [152,153]. Additional methylation events that control recruitment of DDR factors include the methylation marks of DNA-PKcs (K1150me3, K2746me2, and K3248me2) and Ku80 (K7me3) that are recognized by HP1 $\beta$ and required for the proper localization of several factors at the damage sites [154].

In cancer cells, heterochromatin relaxation in response to DNA damage is also affected by the methylation of the methyltransferase SUV39H1 at K105 and K123 by SET7/9 [155], highlighting that, during DDR, a functional interplay between epigenetic enzymes with methyltransferase activity is also possible next to the antagonistic events between KMTs and KDMs described earlier.

Interestingly, it is plausible that the extent of regulation of epigenetic factors on DDR proteins may include protein-protein interactions beyond of their enzymatic activities [156]. In a recent report, Alsulami et al. identified a necessary protein-protein interaction between SET1A and RAD18 for the proper recovery after DNA damage [157]. Similarly, protein-protein associations have been identified between SET1 and BOD1L in protecting replication forks [158] and between SETD1A and cyclin K during DNA repair [159]. 


\subsection{Non-Histone Arginine Methylation}

Methylation of arginine residues are also involved in the complex regulation of DDR and repair processes. So far, four out of nine arginine methyltransferases (PRMTs) have been identified to methylate important DDR factors. PRMT1, the most active enzyme among PRTMs ( $>80 \%$ of all PRMT activity), di-methylates asymmetrically the DDR factor MRE11 that along with RAD50 and NBS1, form the MRN complex, which serves as a primary sensor of DSBs. Arginine methylation of MRE11's RGG/RG motif by PRMT1 has been shown to be essential for its nuclease activity, recruitment at the sites with DSBs, exposure of ssDNA, and initiation of HR repair [160-162]. Interestingly, in vivo substitution of PRMT1 targeted arginines by lysines of MRE11 impaired also the ATR/CHK1 signaling pathway along with defects in cell cycle checkpoints and gross chromosomal aberrations [163]. Similar to MRE11, 53BP1 was also found methylated at its RGG/RG motif (residues R1406 and R1413) by PRTM1, altering its binding capacity to sites with SSBs or DSBs $[164,165]$. On the other hand, BRCA1 methylation by PRMT1 alters BRCA1's efficiency to bind DNA as transcriptional cofactor [166]. PRTM1 and PRTM6 methylate also Pol $\beta$ at R83, R137, and R152 residues. These methylation modifications affect Pol $\beta$ 's interaction with PCNA, and alter its polymerase processivity and DNA binding affinity $[167,168]$.

Like PRMT1, PRMT5 is also involved in the regulation of several DDR factors, with the most important being KLF4 and p53. The transcription factor KLF4 plays primal role in the cellular decision of pursuing DNA damage repair. Upon damage, PRTM5 methylate KLF4 at R374, R376, and R377 and, thus, its degradation is prevented. Accumulating KLF4 was found able to activate p21-dependent cell cycle arrest and inhibition of apoptosis [169]. Methylation of p53 by PRTM5 was demonstrated to induce a p53-dependent cell cycle arrest response, while in the absence of PRTM5, a p53-dependent apoptosis was promoted [170,171]. The FEN1 nuclease (participates on both replication and long-patch BER) is also regulated by PRTM5 on up to four arginine residues (primarily R192). Methylation on these specific sites enhances FEN1-PCNA interaction and promotes the nuclear localization of FEN1 at replication sites during $S$ phase or after genotoxic stress [52,54], highlighting the dynamic interplay between PTMs [172-174].

As mentioned in the previous section, non-enzymatic functions of epigenetic factors are emerging. Accordingly, Hamard et al. reported that DNA repair efficiency is regulated by PRMT5 through its interference on the alternative splicing of key histone modifying and DNA-repair factors, including EZH2, SETDB1, SUV4-20H2, and TIP60, with the latter being particularly involved in the DNA repair of hematopoietic cells [175]. Collectively, the above reports highlight the importance of lysine/arginine methylation in the regulation of numerous non-histone proteins and cellular decisions implicated in DDR or repair processes (Table 1). Of note, such modifications interfere and/or interact with additional PMTs (phosphorylations, ubiquitinations, acetylations), on the same or partner molecules, magnifying the complexity of the DDR regulatory network. The complete picture seems far from solved, as the field is rapidly expanding and the expectations of identifying arginine demethylating enzymes are high [176]. 
Table 1. List of methylated non-histone substrates of epigenetic factors involved in DDR.

\begin{tabular}{|c|c|c|c|c|}
\hline & $\begin{array}{c}\text { DDR } \\
\text { Protein }\end{array}$ & $\begin{array}{l}\text { Methylated } \\
\text { Residue }\end{array}$ & $\begin{array}{l}\text { Epigenetic } \\
\text { Enzyme }\end{array}$ & Effect \\
\hline \multirow{24}{*}{ 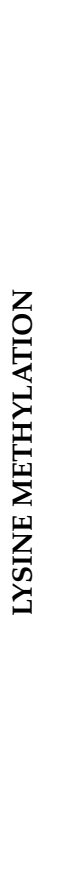 } & TP53 & K370me1 & SMYD2 & repression \\
\hline & & K373me2 & G9/GLP & repression \\
\hline & & K382me1 & SET8 & repression \\
\hline & & K370me2->me1 & LSD1 & repression \\
\hline & & K370me2 & & activation \\
\hline & & K372me1 & SET7 & activation (promotes p53 acetylation) \\
\hline & & K382me2 & & activation \\
\hline & E2F1 & K185 & SET9 LSD1 & suppresses E2F1 accumulation \\
\hline & NUMB & K158 K136 & SET8 & p53 degradation \\
\hline & $\mathbf{R b}$ & & SMYD2 & enhances $\mathrm{Rb}$ phosphorylation \\
\hline & & K810 & SET7 & docking site for 53BP1 \\
\hline & & K860 & SMYD2 & docking site for L3MBTL1 \\
\hline & SITR1 & & SET7 & $\begin{array}{l}\text { prevents SIRT1-p53 interaction, p53 } \\
\text { activation }\end{array}$ \\
\hline & PPP1R12A & K442me1 & SET7 & dephosphorylates $\mathrm{Rb}$ \\
\hline & & K442me1->K442 & LSD1 & unable to dephosphorylate $\mathrm{Rb}$ \\
\hline & PCNA & K248 & SET8 & activation \\
\hline & MDC1 & K45 & JMJD1C & activation \\
\hline & FEN1 & K377 & SET7 & activation \\
\hline & UHRF1 & K385me1 & SET7 & PCNA polyubiquitination \\
\hline & & K385me->K385 & LSD1 & prevents UHRF1-PCNA interaction \\
\hline & PARP1 & K508 K528 & SET7 SMYD2 & enhances PARP1 at damage sites \\
\hline & DNA-PKcs & K1150me3 & & activation \\
\hline & & K2746me2 & & \\
\hline & & K3248me2 & & \\
\hline \multirow{13}{*}{ 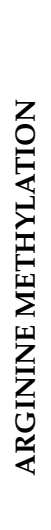 } & KU80 & K7me3 & & activation \\
\hline & SUV39H1 & K105 K123 & SET7 & heterochromatin relaxation \\
\hline & MRE11 & & PRMT1 & activation \\
\hline & 53BP1 & R1406 & PRMT1 & $\begin{array}{c}\text { activation (enhances binding at } \\
\text { damage sites) }\end{array}$ \\
\hline & & R1413 & & \\
\hline & BRCA1 & & PRMT1 & activation \\
\hline & $\operatorname{Pol} \beta$ & R83 & PRMT1 PRMT6 & activation \\
\hline & & R154 & & \\
\hline & KLF4 & R374 & PRMT5 & KLF4 accumulation \\
\hline & & R376 & & \\
\hline & & R377 & & \\
\hline & TP53 & & PRMT5 & activation \\
\hline & FEN1 & R192 & PRMT5 & activation \\
\hline
\end{tabular}

\section{Epigenetic Chromatin Regulation and DNA Repair: Synthetic Lethal Interactions and Clinical Applications}

As illustrated, chromatin regulation and DNA repair have a complex interplay that we only recently have begun to understand. As a result, there is substantial effort to translate these findings for patient benefit, particularly in cancer. A big portion of cancer treatment options rely on killing cancer cells through induction of DNA damage directly by chemotherapy or irradiation, or indirectly through targeting DNA repair. However, high toxicity and refractory or recurrent disease are frequent, which calls for new treatment options and better patient selection. Epigenomic alterations are thought to play an important role in drug resistance by contributing to gene expression plasticity and tumor heterogeneity [177]. Moreover, the interplay between epigenetic regulation and DNA repair can be exploited to achieve greater therapeutic response, by synergistic and synthetic lethal interactions. In this context, chemical inhibition of epigenetic factors that modulate DDR and drug resistance is a promising and attractive avenue for anticancer therapy (Figure 4). 


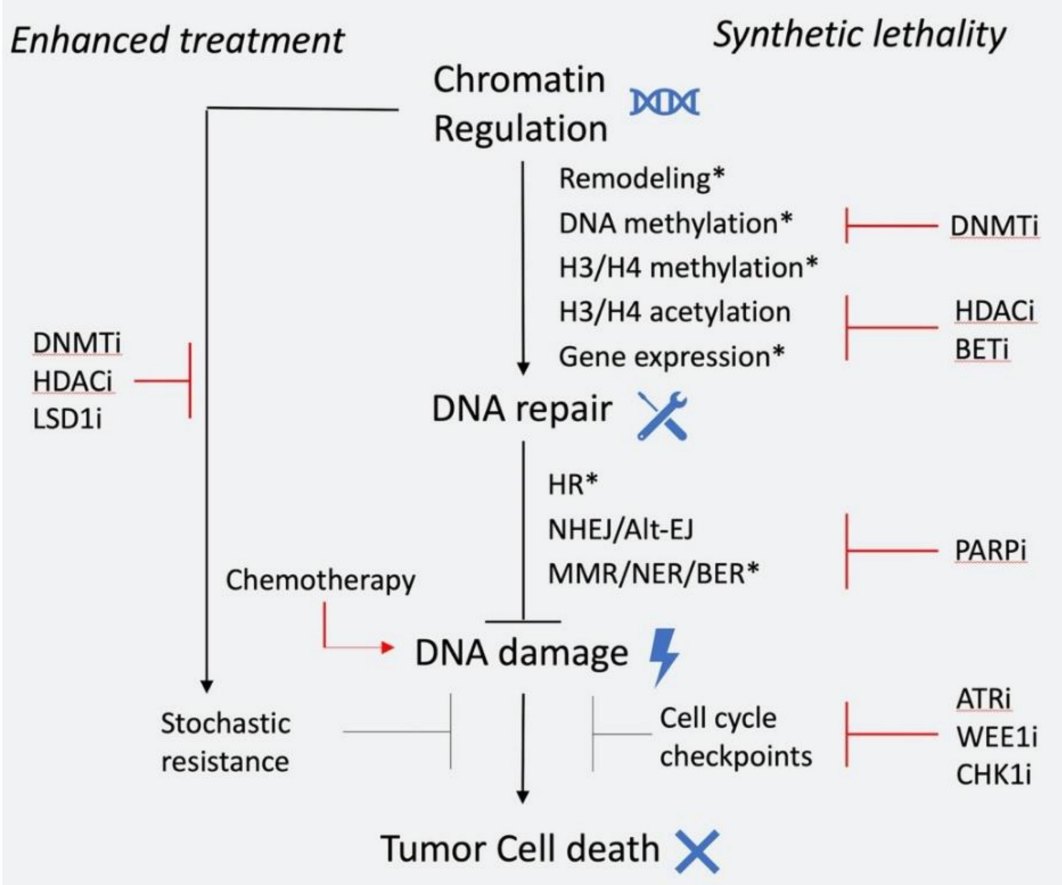

Figure 4. Targeting multiple steps of DNA damage resolution leads to efficient cell killing. Chromatin regulation is necessary for efficient DNA repair. These pathways are often defective in cancer (asterisks *) and can be targeted using specific inhibitors. As a result, synthetic lethal interactions can be exploited with multiple ways, which can be very advantageous in the clinical setting, where changes in treatment are required.

Chromatin regulation is a complex process, that is often disrupted in various ways within cancer cells. Epigenetic drugs that target components of chromatin regulation, such as inhibitors of DNMTs and HDACs have been proven clinically effective mostly in hematopoietic malignancies that are particularly reliant on epigenetic deregulation of progenitor/stem cells [178]. In solid tumors, broad use of epigenetic drugs has been proven ineffective [179] and only targeted approaches such as use of EZH2 a and IDH inhibitors in selected patients seem promising [180]. A synopsis of current epigenetic drugs used in clinic is shown in Table 2. DNA repair is also frequently disrupted in cancer, and multiple approaches based on targeting DNA repair are currently employed in the clinic as reviewed previously [181].

Table 2. Representative epigenetic drugs used in clinic.

\begin{tabular}{|c|c|c|c|c|}
\hline Inhibitor Type & Representative Drugs & Target & Status & Cancer Type \\
\hline \multirow{4}{*}{ HDAC } & Vorinostat & All HDACs & FDA approved & T-cell Lymphoma \\
\hline & Romidepsin & HDAC1-3 & FDA approved & T-cell Lymphoma \\
\hline & Belinostat & All HDACs & FDA approved & T-cell Lymphoma \\
\hline & Panobinostat & All HDACs & FDA approved & $\begin{array}{c}\text { Refractory multiple } \\
\text { myeloma }\end{array}$ \\
\hline \multirow[t]{2}{*}{ BET } & OTX015/MK-8628 & $\mathrm{BRD} 2 / 3 / 4$ & phase $1 b$ & $\begin{array}{l}\text { NUT midline } \\
\text { carcinoma }\end{array}$ \\
\hline & I-BET762 & $\mathrm{BRD} 2 / 3 / 5$ & phase $1 / 2$ & $\begin{array}{l}\text { NUT midline } \\
\text { carcinoma \& } \\
\text { hematological } \\
\text { cancers }\end{array}$ \\
\hline \multirow{2}{*}{ DNMT } & 5-azacitidine & DNMTs & FDA appoved & AML, MDS \\
\hline & Decitabine & DNMTs & FDA appoved & AML, MDS \\
\hline HDM & tranylcypromine & LSD1 & phase 1 & AML \\
\hline \multirow{2}{*}{ HМТ } & tazemetostat & EZH2 & phase $1 / 2$ & B-cell Lymphoma \\
\hline & Pinometostat & DOT1L & phase 1 & MLL-r Leukemia \\
\hline
\end{tabular}




\subsection{Epigenetic Inhibitors in Combination with Chemotherapy/Radiotherapy}

In the context of chromatin regulation and DNA repair, the most explored therapeutic approach so far is combination of epigenetic inhibitors with chemotherapeutic agents. Such combinations have displayed synergistic effects in pre-clinical models. More specifically, HDAC inhibitors have been shown to inhibit the DDR/HR pathway and cause sensitivity to DNA damage-inducing agents in various cell types [124]. Moreover, HDAC, DNMT, and LSD1 inhibitors were shown to counteract epigenetic resistance mechanisms and restore sensitivity to chemotherapy in solid tumors [182-184]. A number of clinical trials were conducted to assess the efficacy of these combinations in treatment of advanced solid tumors with mixed results in terms of patient response and toxicity, likely because of the differences between regimens and cohorts $[185,186]$. It is likely that more targeted approaches will be more beneficial, as in the context of BRF1 or EGFR bearing mutant non-small-cell lung cancers, where EZH2 inhibition was shown to selectively sensitize these tumors to topoisomerase II inhibition [187].

Following the same rationale, epigenetic inhibitors could also potentiate radiotherapy. Preclinical evidence has shown such synergism between radiotherapy and HDAC inhibitors [188,189], BET inhibitors [190], EZH2 inhibitors [191,192], and DNA methyltransferase inhibitors [193]. Of these, only the combination of HDAC inhibitors and irradiation is under assessment in the clinic and initial results indicate high toxicity and only limited patient benefit. DNA methyltransferase inhibitors, such 5-azacytidine and decitabine, are cytidine analogs that are incorporated in DNA and are potent radiosensitizers in all contexts, so this combination is not viable due to high toxicity. Optimization of regimen and dosage will be key to increasing efficacy of these drug combinations in the clinic.

\subsection{Epigenetic Inhibitors in Combination with Drugs that Target DNA Repair Components}

Another therapeutic approach to exploit this interplay is to utilize synthetic lethal interactions. As mentioned above, HDAC inhibitors have been shown to inhibit expression of HR repair genes and this provides a rationale for combing HDAC and PARP inhibitors to achieve effective tumor killing $[194,195]$. Such synergism has been observed in pre-clinical models of prostate, breast, and ovarian cancer [196-199]. The efficacy of combining HDAC and PARP inhibitors is currently under evaluation in the clinic (NCT03742245). Similar effects in the expression of HR components are also observed by BET inhibition [200]. Pre-clinical studies have shown significant synergism between BET and PARP inhibitors in multiple cell types, including breast and ovarian cancer [200-203], which is also under assessment in the clinic (NCT03991469). Combination of PARP and DNA methyltransferase inhibitors has also shown synergistic activity in AML and breast cancer cells [204]. PARP1 and DNMT1 were shown to interact during repair and simultaneous inhibition led to increased PARP1 trapping and DNA damage. A clinical trial is investigating the efficacy of this combination in AML patients (NCT02878785). All the above combinations allow administration of low doses of each drug, which is particularly important for HDAC and DNMT inhibitors, since high toxicity has been a limiting factor to their application. Optimal patient selection and regimen will be crucial to the success of these and future trials.

\subsection{Targeting DNA Repair in Tumors with Epigenetic Alterations}

Another way to take advantage of the interplay between DNA repair and the epigenome is to target DNA repair components in cancer cells with specific epigenomic alterations. An example of this is H3K36me3 loss which occurs in tumors with either mutations in SETD2, the methyltransferase that deposits this mark, or mutations in histone $\mathrm{H} 3$ that inhibit the generation of this modification (e.g., H3K36me3), as well as in tumors that overexpress the demethylases KDM4A and KDM4B [205,206]. These events are frequent in various cancer types, including renal cell carcinoma, lung cancer and glioma [207], and have been associated with poor prognosis [208]. H3K36me3 has been implicated in many DNA repair pathways including HR, NHEJ, and MMR [209]. Pfister et al. identified a dependency of tumors with low H3K36me3 to cell cycle checkpoints, rendering them sensitive to 
WEE1, CHK, and ATR inhibition [210]. This discovery led to the initiation of a clinical trial assessing the use of the WEE1 inhibitor adavosertib in SETD2-deficient solid tumors (NCT03284385). Based on the role of H3K36me3 in other aspects of DNA repair, it would be interesting to examine other potential synthetic lethal interactions in H3K36me3-low tumors such as PARP inhibition.

Another component of chromatin regulation that has been shown to be actively involved in DNA repair pathways is the subunit of the SWI/SNF complex, ARID1A. In solid tumors, this epigenetic factor is frequently mutated and its inactivation has been linked with aggressive disease [211,212]. ARID1A-deficient tumors were shown to have cell cycle defects due to its role in DNA damage response and cell cycle checkpoint regulation [213,214]. Consequently, these tumors were found to be sensitive to PARP and ATR inhibitors. A number of clinical trials are currently investigating the efficacy of targeting ARID1A deficient tumors with these inhibitors in patients (NCT04065269, NCT03207347, NCT04042831).

\section{Concluding Remarks}

Mammalian cells have evolved a complex network of pathways in order to utilize, protect, and preserve their genetic information. This includes pathways dedicated in the maintenance and regulation of chromatin structures, as well as pathways that recognize and repair genomic lesions. As described above, accurate restoration of DNA damage relies on the direct or indirect activity of chromatin regulators. Specifically, DNA repair components depend on extensive alterations in chromatin state in order to access and repair DNA lesions. Moreover, the activity of chromatin regulators is essential for sustained expression and post-translational regulation of these components. As more evidence accumulates and more interactions are uncovered, we gain better understanding of these processes. Given the extensive involvement of chromatin regulation and DNA repair in tumor development, progression, and treatment, comprehension of the complex interplays between them will be crucial for discovery of effective therapeutic approaches. Specifically, there is need for more effective epigenetic and DNA repair drugs, in terms of target specificity and pharmacokinetics. Additionally, therapeutic approaches that rely on synthetic lethal interactions require efficient patient selection based on genetic or phenotypic properties, such as DNA repair proficiency and chromatin state, which is still only partially implemented in cancer therapy. In conclusion, it is an exciting time for both basic researchers exploring the mechanistic interplays between epigenetics and DNA repair, as well as for clinicians that develop new therapeutic approaches.

Author Contributions: T.R.; P.K.; D.K.; writing-review and editing. All authors have read and agreed to the submitted version of the manuscript.

Funding: This research was funded by Hellenic Foundation for Research and Innovation (472-EpiNotch).

Conflicts of Interest: The authors declare no conflict of interest.

\section{References}

1. Waddington, C.H. The epigenotype. Int. J. Epidemiol. 2012, 41, 10-13. [CrossRef] [PubMed]

2. Hershkovitz, M.; Riggs, A.D. Metaphase chromosome analysis by ligation-mediated PCR: Heritable chromatin structure and a comparison of active and inactive X chromosomes. Proc. Natl. Acad. Sci. USA 1995, 92, 2379-2383. [CrossRef] [PubMed]

3. Bird, A. Perceptions of epigenetics. Nature 2007, 447, 396-398. [CrossRef] [PubMed]

4. Mann, J.R. Epigenetics and memigenetics. Cell. Mol. Life. Sci. 2014, 71, 1117-1122. [CrossRef] [PubMed]

5. Goll, M.G.; Bestor, T.H. Eukaryotic cytosine methyltransferases. Annu. Rev. Biochem. 2005, 74, 481-514. [CrossRef]

6. Jenuwein, T.; Allis, C.D. Translating the histone code. Science 2001, 293, 1074-1080. [CrossRef]

7. Smith, C.L.; Peterson, C.L. ATP-dependent chromatin remodeling. Curr. Top. Dev. Biol. 2005, 65, 115-148.

8. Henikoff, S.; Smith, M.M. Histone variants and epigenetics. Cold. Spring. Harb. Perspect. Biol. 2015, 7, a019364. [CrossRef] 
9. Kandoth, C.; McLellan, M.D.; Vandin, F.; Ye, K.; Niu, B.; Lu, C.; Xie, M.; Zhang, Q.; McMichael, J.F.; Wyczalkowski, M.A.; et al. Mutational landscape and significance across 12 major cancer types. Nature 2013, 502, 333-339. [CrossRef]

10. Plass, C.; Pfister, S.M.; Lindroth, A.M.; Bogatyrova, O.; Claus, R.; Lichter, P. Mutations in regulators of the epigenome and their connections to global chromatin patterns in cancer. Nat. Rev. Genet. 2013, 14, 765-780. [CrossRef]

11. Timp, W.; Feinberg, A.P. Cancer as a dysregulated epigenome allowing cellular growth advantage at the expense of the host. Nat. Rev. Cancer 2013, 13, 497-510. [CrossRef] [PubMed]

12. Blanco, E.; Gonzalez-Ramirez, M.; Alcaine-Colet, A.; Aranda, S.; Di Croce, L. The Bivalent Genome: Characterization, Structure, and Regulation. Trends Genet. 2020, 36, 118-131. [CrossRef] [PubMed]

13. Negrini, S.; Gorgoulis, V.G.; Halazonetis, T.D. Genomic instability-An evolving hallmark of cancer. Nat. Rev. Mol. Cell Biol. 2010, 11, 220-228. [CrossRef] [PubMed]

14. Kryston, T.B.; Georgiev, A.B.; Pissis, P.; Georgakilas, A.G. Role of oxidative stress and DNA damage in human carcinogenesis. Mutat. Res. 2011, 711, 193-201. [CrossRef]

15. Patel, D.R.; Weiss, R.S. A tough row to hoe: When replication forks encounter DNA damage. Biochem. Soc. Trans. 2018, 46, 1643-1651. [CrossRef]

16. Khanna, K.K.; Jackson, S.P. DNA double-strand breaks: Signaling, repair and the cancer connection. Nat. Genet. 2001, 27, 247-254. [CrossRef]

17. Cadet, J.; Wagner, J.R. DNA base damage by reactive oxygen species, oxidizing agents, and UV radiation. Cold Spring Harb. Perspect. Biol. 2013, 5, a012559. [CrossRef]

18. Huang, Y.; Li, L. DNA crosslinking damage and cancer-A tale of friend and foe. Transl. Cancer Res. 2013, 2, 144-154.

19. Alexander, J.L.; Orr-Weaver, T.L. Replication fork instability and the consequences of fork collisions from rereplication. Genes Dev. 2016, 30, 2241-2252. [CrossRef]

20. Tanaka, S.; Diffley, J.F. Deregulated G1-cyclin expression induces genomic instability by preventing efficient pre-RC formation. Genes Dev. 2002, 16, 2639-2649. [CrossRef]

21. Bester, A.C.; Roniger, M.; Oren, Y.S.; Im, M.M.; Sarni, D.; Chaoat, M.; Bensimon, A.; Zamir, G.; Shewach, D.S.; Kerem, B. Nucleotide deficiency promotes genomic instability in early stages of cancer development. Cell 2011, 145, 435-446. [CrossRef] [PubMed]

22. Macheret, M.; Halazonetis, T.D. DNA replication stress as a hallmark of cancer. Annu. Rev. Pathol. 2015, 10, 425-448. [CrossRef] [PubMed]

23. Bordelet, H.; Dubrana, K. Keep moving and stay in a good shape to find your homologous recombination partner. Curr. Genet. 2019, 65, 29-39. [CrossRef]

24. Satoh, M.S.; Lindahl, T. Role of poly(ADP-ribose) formation in DNA repair. Nature 1992, 356, $356-358$. [CrossRef] [PubMed]

25. Eustermann, S.; Wu, W.F.; Langelier, M.F.; Yang, J.C.; Easton, L.E.; Riccio, A.A.; Pascal, J.M.; Neuhaus, D. Structural Basis of Detection and Signaling of DNA Single-Strand Breaks by Human PARP-1. Mol. Cell 2015, 60, 742-754. [CrossRef] [PubMed]

26. Myler, L.R.; Gallardo, I.F.; Soniat, M.M.; Deshpande, R.A.; Gonzalez, X.B.; Kim, Y.; Paull, T.T.; Finkelstein, I.J. Single-Molecule Imaging Reveals How Mre11-Rad50-Nbs1 Initiates DNA Break Repair. Mol. Cell 2017, 67, 891-898. [CrossRef] [PubMed]

27. Gibson, B.A.; Kraus, W.L. New insights into the molecular and cellular functions of poly(ADP-ribose) and PARPs. Nat. Rev. Mol. Cell Biol. 2012, 13, 411-424. [CrossRef]

28. Stilmann, M.; Hinz, M.; Arslan, S.C.; Zimmer, A.; Schreiber, V.; Scheidereit, C. A nuclear poly(ADP-ribose)-dependent signalosome confers DNA damage-induced IkappaB kinase activation. Mol. Cell 2009, 36, 365-378. [CrossRef]

29. Uematsu, N.; Weterings, E.; Yano, K.; Morotomi-Yano, K.; Jakob, B.; Taucher-Scholz, G.; Mari, P.O.; van Gent, D.C.; Chen, B.P.; Chen, D.J. Autophosphorylation of DNA-PKCS regulates its dynamics at DNA double-strand breaks. J. Cell Biol. 2007, 177, 219-229. [CrossRef]

30. Wang, M.; Wu, W.; Wu, W.; Rosidi, B.; Zhang, L.; Wang, H.; Iliakis, G. PARP-1 and Ku compete for repair of DNA double strand breaks by distinct NHEJ pathways. Nucleic Acids Res. 2006, 34, 6170-6182. [CrossRef]

31. You, Z.; Chahwan, C.; Bailis, J.; Hunter, T.; Russell, P. ATM activation and its recruitment to damaged DNA require binding to the $\mathrm{C}$ terminus of Nbs1. Mol. Cell Biol. 2005, 25, 5363-5379. [CrossRef] [PubMed] 
32. Celeste, A.; Fernandez-Capetillo, O.; Kruhlak, M.J.; Pilch, D.R.; Staudt, D.W.; Lee, A.; Bonner, R.F.; Bonner, W.M.; Nussenzweig, A. Histone H2AX phosphorylation is dispensable for the initial recognition of DNA breaks. Nat. Cell Biol. 2003, 5, 675-679. [CrossRef] [PubMed]

33. Yuan, J.; Chen, J. MRE11-RAD50-NBS1 complex dictates DNA repair independent of H2AX. J. Biol. Chem. 2010, 285, 1097-1104. [CrossRef] [PubMed]

34. Obmolova, G.; Ban, C.; Hsieh, P.; Yang, W. Crystal structures of mismatch repair protein MutS and its complex with a substrate DNA. Nature 2000, 407, 703-710. [CrossRef]

35. Dip, R.; Camenisch, U.; Naegeli, H. Mechanisms of DNA damage recognition and strand discrimination in human nucleotide excision repair. DNA Repair. 2004, 3, 1409-1423. [CrossRef]

36. Buterin, T.; Meyer, C.; Giese, B.; Naegeli, H. DNA quality control by conformational readout on the undamaged strand of the double helix. Chem. Biol. 2005, 12, 913-922. [CrossRef]

37. Min, J.H.; Pavletich, N.P. Recognition of DNA damage by the Rad4 nucleotide excision repair protein. Nature 2007, 449, 570-575. [CrossRef]

38. Crenshaw, C.M.; Wade, J.E.; Arthanari, H.; Frueh, D.; Lane, B.F.; Nunez, M.E. Hidden in plain sight: Subtle effects of the 8-oxoguanine lesion on the structure, dynamics, and thermodynamics of a 15-base pair oligodeoxynucleotide duplex. Biochemistry 2011, 50, 8463-8477. [CrossRef]

39. Jacobs, A.L.; Schar, P. DNA glycosylases: In DNA repair and beyond. Chromosoma 2012, 121, 1-20. [CrossRef]

40. Smerdon, M.J.; Tlsty, T.D.; Lieberman, M.W. Distribution of ultraviolet-induced DNA repair synthesis in nuclease sensitive and resistant regions of human chromatin. Biochemistry 1978, 17, 2377-2386. [CrossRef]

41. Jaberaboansari, A.; Nelson, G.B.; Roti Roti, J.L.; Wheeler, K.T. Postirradiation alterations of neuronal chromatin structure. Radiat. Res. 1988, 114, 94-104. [CrossRef] [PubMed]

42. Sidik, K.; Smerdon, M.J. Nucleosome rearrangement in human cells following short patch repair of DNA damaged by bleomycin. Biochemistry 1990, 29, 7501-7511. [CrossRef] [PubMed]

43. Aymard, F.; Aguirrebengoa, M.; Guillou, E.; Javierre, B.M.; Bugler, B.; Arnould, C.; Rocher, V.; Iacovoni, J.S.; Biernacka, A.; Skrzypczak, M.; et al. Genome-wide mapping of long-range contacts unveils clustering of DNA double-strand breaks at damaged active genes. Nat. Struct. Mol. Biol. 2017, 24, 353-361. [CrossRef]

44. Arnould, C.; Legube, G. The Secret Life of Chromosome Loops upon DNA Double-Strand Break. J. Mol. Biol. 2020, 432, 724-736. [CrossRef] [PubMed]

45. Hittelman, W.N.; Pollard, M. Visualization of chromatin events associated with repair of ultraviolet light-induced damage by premature chromosome condensation. Carcinogenesis 1984, 5, 1277-1285. [CrossRef] [PubMed]

46. Ljungman, M. Pretreatment with UV light renders the chromatin in human fibroblasts more susceptible to the DNA-damaging agents bleomycin, gamma radiation and 8-methoxypsoralen. Carcinogenesis 1989, 10, 447-451. [CrossRef] [PubMed]

47. Strickfaden, H.; McDonald, D.; Kruhlak, M.J.; Haince, J.F.; Th'ng, J.P.; Rouleau, M.; Ishibashi, T.; Corry, G.N.; Ausio, J.; Underhill, D.A.; et al. Poly(ADP-ribosyl)ation-dependent Transient Chromatin Decondensation and Histone Displacement following Laser Microirradiation. J. Biol. Chem. 2016, 291, 1789-1802. [CrossRef]

48. Kruhlak, M.J.; Celeste, A.; Dellaire, G.; Fernandez-Capetillo, O.; Muller, W.G.; McNally, J.G.; Bazett-Jones, D.P.; Nussenzweig, A. Changes in chromatin structure and mobility in living cells at sites of DNA double-strand breaks. J. Cell. Biol. 2006, 172, 823-834. [CrossRef]

49. Sellou, H.; Lebeaupin, T.; Chapuis, C.; Smith, R.; Hegele, A.; Singh, H.R.; Kozlowski, M.; Bultmann, S.; Ladurner, A.G.; Timinszky, G. The poly(ADP-ribose)-dependent chromatin remodeler Alc1 induces local chromatin relaxation upon DNA damage. Mol. Biol. Cell. 2016, 27, 3791-3799. [CrossRef]

50. Chou, D.M.; Adamson, B.; Dephoure, N.E.; Tan, X.; Nottke, A.C.; Hurov, K.E.; Gygi, S.P.; Colaiacovo, M.P.; Elledge, S.J. A chromatin localization screen reveals poly (ADP ribose)-regulated recruitment of the repressive polycomb and NuRD complexes to sites of DNA damage. Proc. Natl. Acad. Sci. USA 2010, 107, 18475-18480. [CrossRef]

51. Smith, R.; Sellou, H.; Chapuis, C.; Huet, S.; Timinszky, G. CHD3 and CHD4 recruitment and chromatin remodeling activity at DNA breaks is promoted by early poly(ADP-ribose)-dependent chromatin relaxation. Nucleic. Acids Res. 2018, 46, 6087-6098. [CrossRef] [PubMed] 
52. Smeenk, G.; Wiegant, W.W.; Marteijn, J.A.; Luijsterburg, M.S.; Sroczynski, N.; Costelloe, T.; Romeijn, R.J.; Pastink, A.; Mailand, N.; Vermeulen, W.; et al. Poly(ADP-ribosyl)ation links the chromatin remodeler SMARCA5/SNF2H to RNF168-dependent DNA damage signaling. J. Cell. Sci. 2013, 126, 889-903. [CrossRef] [PubMed]

53. Luijsterburg, M.S.; de Krijger, I.; Wiegant, W.W.; Shah, R.G.; Smeenk, G.; de Groot, A.J.L.; Pines, A.; Vertegaal, A.C.O.; Jacobs, J.J.L.; Shah, G.M.; et al. PARP1 Links CHD2-Mediated Chromatin Expansion and H3.3 Deposition to DNA Repair by Non-homologous End-Joining. Mol. Cell. 2016, 61, 547-562. [CrossRef] [PubMed]

54. Iacovoni, J.S.; Caron, P.; Lassadi, I.; Nicolas, E.; Massip, L.; Trouche, D.; Legube, G. High-resolution profiling of gammaH2AX around DNA double strand breaks in the mammalian genome. EMBO J. 2010, 29, 1446-1457. [CrossRef] [PubMed]

55. Bird, A.W.; Yu, D.Y.; Pray-Grant, M.G.; Qiu, Q.; Harmon, K.E.; Megee, P.C.; Grant, P.A.; Smith, M.M.; Christman, M.F. Acetylation of histone $\mathrm{H} 4$ by Esa1 is required for DNA double-strand break repair. Nature 2002, 419, 411-415. [CrossRef] [PubMed]

56. Zhang, R.; Erler, J.; Langowski, J. Histone Acetylation Regulates Chromatin Accessibility: Role of H4K16 in Inter-nucleosome Interaction. Biophys. J. 2017, 112, 450-459. [CrossRef] [PubMed]

57. Dhar, S.; Gursoy-Yuzugullu, O.; Parasuram, R.; Price, B.D. The tale of a tail: Histone H4 acetylation and the repair of DNA breaks. Philos. Trans. R Soc. Lond. B Biol. Sci. 2017, 372, 20160284. [CrossRef]

58. Chiolo, I.; Minoda, A.; Colmenares, S.U.; Polyzos, A.; Costes, S.V.; Karpen, G.H. Double-strand breaks in heterochromatin move outside of a dynamic HP1a domain to complete recombinational repair. Cell 2011, 144, 732-744. [CrossRef]

59. Goodarzi, A.A.; Noon, A.T.; Deckbar, D.; Ziv, Y.; Shiloh, Y.; Lobrich, M.; Jeggo, P.A. ATM signaling facilitates repair of DNA double-strand breaks associated with heterochromatin. Mol. Cell 2008, 31, 167-177. [CrossRef]

60. Goodarzi, A.A.; Kurka, T.; Jeggo, P.A. KAP-1 phosphorylation regulates CHD3 nucleosome remodeling during the DNA double-strand break response. Nat. Struct. Mol. Biol. 2011, 18, 831-839. [CrossRef]

61. Sun, Y.; Jiang, X.; Xu, Y.; Ayrapetov, M.K.; Moreau, L.A.; Whetstine, J.R.; Price, B.D. Histone H3 methylation links DNA damage detection to activation of the tumour suppressor Tip60. Nat. Cell Biol. 2009, 11, 1376-1382. [CrossRef] [PubMed]

62. Caridi, C.P.; D'Agostino, C.; Ryu, T.; Zapotoczny, G.; Delabaere, L.; Li, X.; Khodaverdian, V.Y.; Amaral, N.; Lin, E.; Rau, A.R.; et al. Nuclear F-actin and myosins drive relocalization of heterochromatic breaks. Nature 2018, 559, 54-60. [CrossRef] [PubMed]

63. Ryu, T.; Spatola, B.; Delabaere, L.; Bowlin, K.; Hopp, H.; Kunitake, R.; Karpen, G.H.; Chiolo, I. Heterochromatic breaks move to the nuclear periphery to continue recombinational repair. Nat. Cell Biol. 2015, 17, 1401-1411. [CrossRef] [PubMed]

64. Colmenares, S.U.; Swenson, J.M.; Langley, S.A.; Kennedy, C.; Costes, S.V.; Karpen, G.H. Drosophila Histone Demethylase KDM4A Has Enzymatic and Non-enzymatic Roles in Controlling Heterochromatin Integrity. Dev. Cell 2017, 42, 156-169. [CrossRef] [PubMed]

65. Tsouroula, K.; Furst, A.; Rogier, M.; Heyer, V.; Maglott-Roth, A.; Ferrand, A.; Reina-San-Martin, B.; Soutoglou, E. Temporal and Spatial Uncoupling of DNA Double Strand Break Repair Pathways within Mammalian Heterochromatin. Mol. Cell 2016, 63, 293-305. [CrossRef]

66. Van Attikum, H.; Fritsch, O.; Gasser, S.M. Distinct roles for SWR1 and INO80 chromatin remodeling complexes at chromosomal double-strand breaks. EMBO J. 2007, 26, 4113-4125. [CrossRef]

67. Lademann, C.A.; Renkawitz, J.; Pfander, B.; Jentsch, S. The INO80 Complex Removes H2A.Z to Promote Presynaptic Filament Formation during Homologous Recombination. Cell Rep. 2017, 19, 1294-1303. [CrossRef]

68. Xu, Y.; Ayrapetov, M.K.; Xu, C.; Gursoy-Yuzugullu, O.; Hu, Y.; Price, B.D. Histone H2A.Z controls a critical chromatin remodeling step required for DNA double-strand break repair. Mol. Cell 2012, 48, 723-733. [CrossRef]

69. Murr, R.; Loizou, J.; Yang, Y.-G.; Cuenin, C.; Li, H.; Wang, Z.-Q.; Herceg, Z. Histone acetylation by Trrap-Tip60 modulates loading of repair proteins and repair of DNA double-strand breaks. Nature 2005, 8, 91-99. [CrossRef] 
70. Pfister, S.X.; Ahrabi, S.; Zalmas, L.-P.; Sarkar, S.; Aymard, F.; Bachrati, C.Z.; Helleday, T.; Legube, G.; La Thangue, N.B.; Porter, A.C.; et al. SETD2-dependent histone H3K36 trimethylation is required for homologous recombination repair and genome stability. Cell Rep. 2014, 7, 2006-2018. [CrossRef]

71. Sanders, S.L.; Portoso, M.; Mata, J.; Bähler, J.; Allshire, R.C.; Kouzarides, T. Methylation of Histone H4 Lysine 20 Controls Recruitment of Crb2 to Sites of DNA Damage. Cell 2004, 119, 603-614. [CrossRef] [PubMed]

72. Saredi, G.; Huang, H.; Hammond, C.M.; Alabert, C.; Bekker-Jensen, S.; Forné, I.; Reverón-Gómez, N.; Foster, B.; Mlejnkova, L.; Bartke, T.; et al. H4K20me0 marks post-replicative chromatin and recruits the TONSL-MMS22L DNA repair complex. Nature 2016, 534, 714-718. [CrossRef] [PubMed]

73. Tuzon, C.; Spektor, T.; Kong, X.; Congdon, L.M.; Wu, S.; Schotta, G.; Yokomori, K.; Rice, J.C. Concerted activities of distinct H4K20 methyltransferases at DNA double-strand breaks regulate 53BP1 nucleation and NHEJ-directed repair. Cell Rep. 2014, 8, 430-438. [CrossRef] [PubMed]

74. Drummond, J.; Li, G.-M.; Longley, M.; Modrich, P. Isolation of an hMSH2-p160 heterodimer that restores DNA mismatch repair to tumor cells. Science 1995, 268, 1909-1912. [CrossRef]

75. Kadyrov, F.A.; Dzantiev, L.; Constantin, N.; Modrich, P.L. Endonucleolytic Function of MutL $\alpha$ in Human Mismatch Repair. Cell 2006, 126, 297-308. [CrossRef]

76. Li, G.-M. Decoding the histone code: Role of H3K36me3 in mismatch repair and implications for cancer susceptibility and therapy. Cancer Res. 2013, 73, 6379-6383. [CrossRef]

77. Huang, Y.; Gu, L.; Li, G.-M. H3K36me3-mediated mismatch repair preferentially protects actively transcribed genes from mutation. J. Boil. Chem. 2018, 293, 7811-7823. [CrossRef]

78. Li, F.; Mao, G.; Tong, D.; Huang, J.; Gu, L.; Yang, W.; Li, G.-M. The Histone Mark H3K36me3 Regulates Human DNA Mismatch Repair through its Interaction with MutS $\alpha$. Cell 2013, 153, 590-600. [CrossRef]

79. Terui, R.; Nagao, K.; Kawasoe, Y.; Taki, K.; Higashi, T.L.; Tanaka, S.; Nakagawa, T.; Obuse, C.; Masukata, H.; Takahashi, T. Nucleosomes around a mismatched base pair are excluded via an Msh2-dependent reaction with the aid of SNF2 family ATPase Smarcad1. Genome Res. 2018, 32, 806-821. [CrossRef]

80. Hause, R.; Pritchard, C.C.; Shendure, J.; Salipante, S.J. Classification and characterization of microsatellite instability across 18 cancer types. Nat. Med. 2016, 22, 1342-1350. [CrossRef]

81. Brooks, S.C.; Adhikary, S.; Rubinson, E.H.; Eichman, B.F. Recent advances in the structural mechanisms of DNA glycosylases. Biochim. Biophys. Acta BBA Proteins Proteom. 2013, 1834, 247-271. [CrossRef] [PubMed]

82. Hegde, M.L.; Hazra, T.K.; Mitra, S. Early steps in the DNA base excision/single-strand interruption repair pathway in mammalian cells. Cell Res. 2008, 18, 27-47. [CrossRef] [PubMed]

83. Robertson, A.B.; Klungland, A.; Rognes, T.; Leiros, I. DNA Repair in Mammalian Cells. Cell. Mol. Life Sci. 2009, 66, 981-993. [CrossRef] [PubMed]

84. Lieber, M.R. The FEN-1 family of structure-specific nucleases in eukaryotic dna replication, recombination and repair. BioEssays 1997, 19, 233-240. [CrossRef]

85. Li, C.; Delaney, S. Challenges for base excision repair enzymes: Acquiring access to damaged DNA in chromatin. Pept. Cancer Derived Enzyme Product. 2019, 45, 27-57. [CrossRef]

86. Menoni, H.; Gasparutto, D.; Hamiche, A.; Cadet, J.; Dimitrov, S.; Bouvet, P.; Angelov, D. ATP-Dependent Chromatin Remodeling Is Required for Base Excision Repair in Conventional but Not in Variant H2A.Bbd Nucleosomes. Mol. Cell. Boil. 2007, 27, 5949-5956. [CrossRef]

87. Menoni, H.; Shukla, M.S.; Gerson, V.; Dimitrov, S.; Angelov, D. Base excision repair of 8-oxoG in dinucleosomes. Nucleic Acids Res. 2011, 40, 692-700. [CrossRef]

88. Nakanishi, S.; Prasad, R.; Wilson, S.H.; Smerdon, M.J. Different structural states in oligonucleosomes are required for early versus late steps of base excision repair. Nucleic Acids Res. 2007, 35, 4313-4321. [CrossRef]

89. Schärer, O.D. Nucleotide Excision Repair in Eukaryotes. Cold Spring Harb. Perspect. Boil. 2013, 5, a012609. [CrossRef]

90. Gaillard, H.; Fitzgerald, D.J.; Smith, C.L.; Peterson, C.L.; Richmond, T.J.; Thoma, F. Chromatin Remodeling Activities Act on UV-damaged Nucleosomes and Modulate DNA Damage Accessibility to Photolyase. J. Boil. Chem. 2003, 278, 17655-17663. [CrossRef]

91. Hara, R.; Sancar, A. The SWI/SNF Chromatin-Remodeling Factor Stimulates Repair by Human Excision Nuclease in the Mononucleosome Core Particle. Mol. Cell. Boil. 2002, 22, 6779-6787. [CrossRef] [PubMed]

92. Zhao, Q.; Wang, Q.-E.; Ray, A.; Wani, G.; Han, C.; Milum, K.; Wani, A.A. Modulation of Nucleotide Excision Repair by Mammalian SWI/SNF Chromatin-remodeling Complex. J. Boil. Chem. 2009, 284, 30424-30432. [CrossRef] [PubMed] 
93. Kothandapani, A.; Gopalakrishnan, K.; Kahali, B.; Reisman, D.; Patrick, S.M. Downregulation of SWI/SNF chromatin remodeling factor subunits modulates cisplatin cytotoxicity. Exp. Cell Res. 2012, 318, 1973-1986. [CrossRef] [PubMed]

94. Banin, S.; Moyal, L.; Shieh, S.-Y.; Taya, Y.; Anderson, C.W.; Chessa, L.; Smorodinsky, N.I.; Prives, C.; Reiss, Y.; Shiloh, Y.; et al. Enhanced Phosphorylation of p53 by ATM in Response to DNA Damage. Science 1998, 281, 1674-1677. [CrossRef]

95. Shieh, S.-Y.; Ahn, J.; Tamai, K.; Taya, Y.; Prives, C. The human homologs of checkpoint kinases Chk1 and Cds1 (Chk2) phosphorylate p53 at multiple DNA damage-inducible sites. Genome Res. 2000, 14, $289-300$.

96. Adimoolam, S.; Ford, J.M. p53 and DNA damage-inducible expression of the xeroderma pigmentosum group C gene. Proc. Natl. Acad. Sci. USA 2002, 99, 12985-12990. [CrossRef]

97. Myung, K.; Braastad, C.; He, D.M.; Hendrickson, E.A. KARP-1 is induced by DNA damage in a p53- and ataxia telangiectasia mutated-dependent fashion. Proc. Natl. Acad. Sci. USA 1998, 95, 7664-7669. [CrossRef]

98. Poletto, M.; Legrand, A.; Fletcher, S.C.; Dianov, G.L. p53 coordinates base excision repair to prevent genomic instability. Nucleic Acids Res. 2016, 44, 3165-3175. [CrossRef]

99. Scherer, S.J.; Maier, S.M.; Seifert, M.; Hanselmann, R.G.; Zang, K.D.; Muller-Hermelink, H.K.; Angel, P.; Welter, C.; Schartl, M. p53 and c-Jun functionally synergize in the regulation of the DNA repair gene hMSH2 in response to UV. J. Biol. Chem. 2000, 275, 37469-37473. [CrossRef]

100. Tibbetts, R.S.; Cortez, D.; Brumbaugh, K.M.; Scully, R.; Livingston, D.; Elledge, S.J.; Abraham, R.T. Functional interactions between BRCA1 and the checkpoint kinase ATR during genotoxic stress. Genome Res. 2000, 14, 2989-3002. [CrossRef]

101. Hartman, A.-R.; Ford, J.M. BRCA1 induces DNA damage recognition factors and enhances nucleotide excision repair. Nat. Genet. 2002, 32, 180-184. [CrossRef] [PubMed]

102. Mullan, P.B.; E Quinn, J.; Harkin, D.P. The role of BRCA1 in transcriptional regulation and cell cycle control. Oncogene 2006, 25, 5854-5863. [CrossRef] [PubMed]

103. Habraken, Y.; Piette, J. NF-kB activation by double-strand breaks. Biochem. Pharmacol. 2006, 72, $1132-1141$. [CrossRef] [PubMed]

104. Lavon, I.; Fuchs, D.; Zrihan, D.; Efroni, G.; Zelikovitch, B.; Fellig, Y.; Siegal, T. Novel Mechanism whereby Nuclear Factor B Mediates DNA Damage Repair through Regulation of O6-Methylguanine-DNA-Methyltransferase. Cancer Res. 2007, 67, 8952-8959. [CrossRef] [PubMed]

105. Wu, K.; Jiang, S.W.; Thangaraju, M.; Wu, G.; Couch, F.J. Induction of the BRCA2 promoter by nuclear factor-kappa B. J. Biol. Chem. 2000, 275, 35548-35556. [CrossRef] [PubMed]

106. Yu, Y.; Yang, J.; Zhu, F.; Xu, F. Response of REV3 promoter to N-methyl-N'-nitro-N-nitrosoguanidine. Mutat. Res. Mol. Mech. Mutagen. 2004, 550, 49-58. [CrossRef]

107. Rezatabar, S.; Karimian, A.; Rameshknia, V.; Parsian, H.; Majidinia, M.; Kopi, T.A.; Bishayee, A.; Sadeghinia, A.; Yousefi, M.; Monirialamdari, M.; et al. RAS/MAPK signaling functions in oxidative stress, DNA damage response and cancer progression. J. Cell. Physiol. 2019, 234, 14951-14965. [CrossRef]

108. Boldogh, I.; Ramana, C.V.; Chen, Z.; Biswas, T.; Hazra, T.K.; Grösch, S.; Grombacher, T.; Mitra, S.; Kaina, B. Regulation of expression of the DNA repair gene O6-methylguanine-DNA methyltransferase via protein kinase C-mediated signaling. Cancer Res. 1998, 58, 3950-3956.

109. Chang, H.W.; Lai, Y.C.; Cheng, C.Y.; Ho, J.L.; Ding, S.T.; Liu, Y.C. UV inducibility of rat proliferating cell nuclear antigen gene promoter. J. Cell. Biochem. 1999, 73, 423-432. [CrossRef]

110. Das, A.; Hazra, T.K.; Boldogh, I.; Mitra, S.; Bhakat, K.K. Induction of the Human Oxidized Base-specific DNA Glycosylase NEIL1 by Reactive Oxygen Species. J. Boil. Chem. 2005, 280, 35272-35280. [CrossRef]

111. Humbert, O.; Achour, I.; Lautier, D.; Laurent, G.; Salles, B. hMSH2 expression is driven by AP1-dependent regulation through phorbol-ester exposure. Nucleic Acids Res. 2003, 31, 5627-5634. [CrossRef] [PubMed]

112. Youn, C.-K.; Kim, M.-H.; Cho, H.-J.; Chang, I.-Y.; Chung, M.-H.; You, H.J. Oncogenic H-Ras Up-Regulates Expression of ERCC1 to Protect Cells from Platinum-Based Anticancer Agents. Cancer Res. 2004, 64, 4849-4857. [CrossRef] [PubMed]

113. Miyakura, Y.; Sugano, K.; Konishi, F.; Ichikawa, A.; Maekawa, M.; Shitoh, K.; Igarashi, S.; Kotake, K.; Koyama, Y.; Nagai, H. Extensive methylation of hMLH1 promoter region predominates in proximal colon cancer with microsatellite instability. Gastroenterology 2001, 121, 1300-1309. [CrossRef] [PubMed]

114. Lax, S.F. Pathology of Endometrial Carcinoma. Adv. Exp. Med. Biol. 2016, 943, 75-96. [CrossRef] 
115. Wang, Y.C.; Lu, Y.P.; Tseng, R.C.; Lin, R.K.; Chang, J.W.; Chen, J.T.; Shih, C.M.; Chen, C.Y. Inactivation of hMLH1 and hMSH2 by promoter methylation in primary non-small cell lung tumors and matched sputum samples. J. Clin. Investig. 2003, 111, 887-895. [CrossRef]

116. Demokan, S.; Suoglu, Y.; Demir, D.; Gozeler, M.; Dalay, N. Microsatellite instability and methylation of the DNA mismatch repair genes in head and neck cancer. Ann. Oncol. 2006, 17, 995-999. [CrossRef]

117. Furihata, M.; Takeuchi, T.; Ohtsuki, Y.; Terao, N.; Kuwahara, M.; Shuin, T. Genetic analysis of hMLH1 in transitional cell carcinoma of the urinary tract: Promoter methylation or mutation. J. Urol. 2001, 165, 1760-1764. [CrossRef]

118. Liu, Q.; Thoms, J.A.; Nunez, A.C.; Huang, Y.; Knezevic, K.; Packham, D.; Poulos, R.C.; Williams, R.L.; Beck, D.; Hawkins, N.; et al. Disruption of a $-35 \mathrm{~kb}$ Enhancer Impairs CTCF Binding and MLH1 Expression in Colorectal Cells. Clin. Cancer Res. 2018, 24, 4602-4611. [CrossRef]

119. George, J.; Alsop, K.; Etemadmoghadam, D.; Hondow, H.; Mikeska, T.; Dobrovic, A.; DeFazio, A.; Smyth, G.K.; Levine, U.A.; Mitchell, G.; et al. Nonequivalent Gene Expression and Copy Number Alterations in High-Grade Serous Ovarian Cancers with BRCA1 and BRCA2 Mutations. Clin. Cancer Res. 2013, 19, 3474-3484. [CrossRef]

120. Zhang, L.; Long, X. Association of BRCA1 promoter methylation with sporadic breast cancers: Evidence from 40 studies. Sci. Rep. 2015, 5, 17869. [CrossRef]

121. Chen, H.-Y.; Shao, C.-J.; Chen, F.-R.; Kwan, A.-L.; Chen, Z.-P. Role of ERCC1 promoter hypermethylation in drug resistance to cisplatin in human gliomas. Int. J. Cancer 2009, 126, 1944-1954. [CrossRef] [PubMed]

122. Rampias, T.; Karagiannis, D.; Avgeris, M.; Polyzos, A.; Kokkalis, A.; Kanaki, Z.; Kousidou, E.; Tzetis, M.; Kanavakis, E.; Stravodimos, K.; et al. The lysine-specific methyltransferase KMT 2C/MLL 3 regulates DNA repair components in cancer. EMBO Rep. 2019, 20, e46821. [CrossRef] [PubMed]

123. Zeidler, M.; Varambally, S.; Cao, Q.; Chinnaiyan, A.M.; Ferguson, D.O.; Merajver, S.D.; Kleer, C.G. The Polycomb Group Protein EZH2 Impairs DNA Repair in Breast Epithelial Cells. Neoplasia 2005, 7, 1011-1019. [CrossRef] [PubMed]

124. Thurn, K.T.; Thomas, S.; Raha, P.; Qureshi, I.; Munster, P. Histone deacetylase regulation of ATM-mediated DNA damage signaling. Mol. Cancer Ther. 2013, 12, 2078-2087. [CrossRef]

125. Friedman, R.; Farh, K.K.-H.; Burge, C.B.; Bartel, B. Most mammalian mRNAs are conserved targets of microRNAs. Genome Res. 2008, 19, 92-105. [CrossRef]

126. Dai, E.; Yu, X.; Zhang, Y.; Meng, F.; Wang, S.; Liu, X.; Liu, D.; Wang, J.; Li, X.; Jiang, W. EpimiR: A database of curated mutual regulation between miRNAs and epigenetic modifications. Database 2014, 2014, bau023. [CrossRef]

127. Realet, E.; Tavernat, D.; Cantini, L.; Martignetti, L.; Osella, M.; De Pittà, C.; Virga, F.; Orso, F.; Caselleł, M. Investigating the epi-miRNome: Identification of epi-miRNAs using transfection experiments. Epigenomics 2019, 11, 1581-1599. [CrossRef]

128. Gruber, A.J.; Zavolan, M. Modulation of epigenetic regulators and cell fate decisions by miRNAs. Epigenomics 2013, 5, 671-683. [CrossRef]

129. Fabbri, M.; Garzon, R.; Cimmino, A.; Liu, Z.; Zanesi, N.; Callegari, E.; Liu, S.; Alder, H.; Costinean, S.; Fernandez-Cymering, C.; et al. MicroRNA-29 family reverts aberrant methylation in lung cancer by targeting DNA methyltransferases 3A and 3B. Proc. Natl. Acad. Sci. USA 2007, 104, 15805-15810. [CrossRef]

130. Ugalde, A.P.; Ramsay, A.J.; De La Rosa, J.; Varela, I.; Mariño, G.; Cadiñanos, J.; Lu, J.; Freije, J.M.P.; Lopez-Otin, C. Aging and chronic DNA damage response activate a regulatory pathway involving miR-29 and p53. EMBO J. 2011, 30, 2219-2232. [CrossRef]

131. Lyu, G.; Guan, Y.; Zhang, C.; Zong, L.; Sun, L.; Huang, X.; Huang, L.; Zhang, L.; Tian, X.L.; Zhou, Z.; et al. TGF-beta signaling alters H4K20me3 status via miR-29 and contributes to cellular senescence and cardiac aging. Nat. Commun. 2018, 9, 2560. [CrossRef] [PubMed]

132. Koturbash, I.; Zemp, F.; Kolb, B.E.; Kovalchuk, O. Sex-specific radiation-induced microRNAome responses in the hippocampus, cerebellum and frontal cortex in a mouse model. Mutat. Res. Toxicol. Environ. Mutagen. 2011, 722, 114-118. [CrossRef] [PubMed]

133. Spaety, M.E.; Gries, A.; Badie, A.; Venkatasamy, A.; Romain, B.; Orvain, C.; Yanagihara, K.; Okamoto, K.; Jung, A.C.; Mellitzer, G.; et al. HDAC4 Levels Control Sensibility toward Cisplatin in Gastric Cancer via the p53-p73/BIK Pathway. Cancers 2019, 11, 1747. [CrossRef] [PubMed]

134. Duru, N.; Gernapudi, R.; Zhang, Y.; Yao, Y.; Lo, P.K.; Wolfson, B.; Zhou, Q. NRF2/miR-140 signaling confers radioprotection to human lung fibroblasts. Cancer Lett. 2015, 369, 184-191. [CrossRef] 
135. Du, Y.; Liu, J.; Zhu, Y.; Yuan, X.; Gao, J.; Cheng, J.; Yan, X. Diesel exhaust particles induce toxicity to beta cells by suppressing miR-140-5p. Int. J. Clin. Exp. Pathol. 2019, 12, 2858-2866.

136. Mueller, A.C.; Sun, D.; Dutta, A. The miR-99 family regulates the DNA damage response through its target SNF2H. Oncogene 2012, 32, 1164-1172. [CrossRef]

137. Biggar, K.K.; Li, S.S.-C. Non-histone protein methylation as a regulator of cellular signalling and function. Nat. Rev. Mol. Cell Boil. 2014, 16, 5-17. [CrossRef]

138. Hamamoto, R.; Saloura, V.; Nakamura, Y. Critical roles of non-histone protein lysine methylation in human tumorigenesis. Nat. Rev. Cancer 2015, 15, 110-124. [CrossRef]

139. Huang, J.; Berger, S. The emerging field of dynamic lysine methylation of non-histone proteins. Curr. Opin. Genet. Dev. 2008, 18, 152-158. [CrossRef]

140. Chuikov, S.; Kurash, J.K.; Wilson, J.R.; Xiao, B.; Justin, N.; Ivanov, G.S.; McKinney, K.; Tempst, P.; Prives, C.; Gamblin, S.; et al. Regulation of p53 activity through lysine methylation. Nature 2004, 432, 353-360. [CrossRef]

141. Huang, J.; Perez-Burgos, L.; Placek, B.J.; Sengupta, R.; Richter, M.; Dorsey, J.A.; Kubicek, S.; Opravil, S.; Jenuwein, T.; Berger, S. Repression of p53 activity by Smyd2-mediated methylation. Nature 2006, 444, 629-632. [CrossRef] [PubMed]

142. Shi, X.; Kachirskaia, I.; Yamaguchi, H.; West, L.E.; Wen, H.; Wang, E.W.; Dutta, S.; Appella, E.; Gozani, O. Modulation of p53 Function by SET8-Mediated Methylation at Lysine 382. Mol. Cell 2007, 27, 636-646. [CrossRef] [PubMed]

143. Huang, J.; Dorsey, J.; Chuikov, S.; Perez-Burgos, L.; Zhang, X.; Jenuwein, T.; Reinberg, D.; Berger, S.L. G9a and Glp methylate lysine 373 in the tumor suppressor p53. J. Biol. Chem. 2010, 285, 9636-9641. [CrossRef] [PubMed]

144. Huang, J.; Sengupta, R.; Espejo, A.; Lee, M.G.; Dorsey, J.A.; Richter, M.; Opravil, S.; Shiekhattar, R.; Bedford, M.T.; Jenuwein, T.; et al. p53 is regulated by the lysine demethylase LSD1. Nature 2007, 449, 105-108. [CrossRef] [PubMed]

145. Shi, Y.; Lan, F.; Matson, C.; Mulligan, P.; Whetstine, J.R.; Cole, P.A.; Casero, R.A.; Shi, Y. Histone Demethylation Mediated by the Nuclear Amine Oxidase Homolog LSD1. Cell 2004, 119, 941-953. [CrossRef] [PubMed]

146. Kurash, J.K.; Lei, H.; Shen, Q.; Marston, W.L.; Granda, B.W.; Fan, H.; Wall, D.; Li, E.; Gaudet, F. Methylation of p53 by Set7/9 mediates p53 acetylation and activity in vivo. Mol. Cell 2008, 29, 392-400. [CrossRef] [PubMed]

147. Kontaki, H.; Talianidis, I. Lysine Methylation Regulates E2F1-Induced Cell Death. Mol. Cell 2010, 39, 152-160. [CrossRef]

148. Saddic, L.A.; West, L.E.; Aslanian, A.; Yates, J.R.; Rubin, S.M.; Gozani, O.; Sage, J. Methylation of the Retinoblastoma Tumor Suppressor by SMYD2. J. Boil. Chem. 2010, 285, 37733-37740. [CrossRef]

149. Cho, H.-S.; Hayami, S.; Toyokawa, G.; Maejima, K.; Yamane, Y.; Suzuki, T.; Dohmae, N.; Kogure, M.; Kang, D.; Neal, D.E.; et al. RB1 Methylation by SMYD2 Enhances Cell Cycle Progression through an Increase of RB1 Phosphorylation. Neoplasia 2012, 14, 476-IN8. [CrossRef]

150. Thandapani, P.; Couturier, A.; Yu, Z.; Li, X.; Couture, J.-F.; Li, S.; Masson, J.-Y.; Richard, S. Lysine methylation of FEN1 by SET7 is essential for its cellular response to replicative stress. Oncotarget 2017, 8, 64918-64931. [CrossRef]

151. Hahm, J.Y.; Kim, J.Y.; Park, J.W.; Kang, J.Y.; Kim, K.B.; Kim, S.R.; Cho, H.; Seo, S.B. Methylation of UHRF1 by SET7 is essential for DNA double-strand break repair. Nucleic Acids Res. 2019, 47, 184-196. [CrossRef] [PubMed]

152. Kassner, I.; Andersson, A.; Fey, M.; Tomas, M.; Ferrando-May, E.; Hottiger, M.O. SET7/9-dependent methylation of ARTD1 at K508 stimulates poly-ADP-ribose formation after oxidative stress. Open Biol. 2013, 3, 120173. [CrossRef] [PubMed]

153. Piao, L.; Kang, D.; Suzuki, T.; Masuda, A.; Dohmae, N.; Nakamura, Y.; Hamamoto, R. The histone methyltransferase SMYD2 methylates PARP1 and promotes poly(ADP-ribosyl)ation activity in cancer cells. Neoplasia 2014, 16, 257-264. [CrossRef] [PubMed]

154. Liu, H.; Galka, M.; Mori, E.; Liu, X.; Lin, Y.F.; Wei, R.; Pittock, P.; Voss, C.; Dhami, G.; Li, X.; et al. A method for systematic mapping of protein lysine methylation identifies functions for HP1beta in DNA damage response. Mol. Cell 2013, 50, 723-735. [CrossRef] 
155. Wang, D.; Zhou, J.; Liu, X.; Lu, D.; Shen, C.; Du, Y.; Wei, F.Z.; Song, B.; Lu, X.; Yu, Y.; et al. Methylation of SUV39H1 by SET7/9 results in heterochromatin relaxation and genome instability. Proc. Natl. Acad. Sci. USA 2013, 110, 5516-5521. [CrossRef]

156. Karakaidos, P.; Verigos, J.; Magklara, A. LSD1/KDM1A, a Gate-Keeper of Cancer Stemness and a Promising Therapeutic Target. Cancers 2019, 11, 1821. [CrossRef]

157. Alsulami, M.; Munawar, N.; Dillon, E.; Oliviero, G.; Wynne, K.; Alsolami, M.; Moss, C.; O'Gaora, P.; O'Meara, F.; Cotter, D.; et al. SETD1A Methyltransferase Is Physically and Functionally Linked to the DNA Damage Repair Protein RAD18. Mol. Cell Proteom. 2019, 18, 1428-1436. [CrossRef]

158. Higgs, M.R.; Reynolds, J.J.; Winczura, A.; Blackford, A.N.; Borel, V.; Miller, E.S.; Zlatanou, A.; Nieminuszczy, J.; Ryan, E.L.; Davies, N.J.; et al. BOD1L Is Required to Suppress Deleterious Resection of Stressed Replication Forks. Mol. Cell 2015, 59, 462-477. [CrossRef]

159. Hoshii, T.; Cifani, P.; Feng, Z.; Huang, C.H.; Koche, R.; Chen, C.W.; Delaney, C.D.; Lowe, S.W.; Kentsis, A.; Armstrong, S.A. A Non-catalytic Function of SETD1A Regulates Cyclin K and the DNA Damage Response. Cell 2018, 172, 1007-1021. [CrossRef]

160. Dery, U.; Coulombe, Y.; Rodrigue, A.; Stasiak, A.; Richard, S.; Masson, J.Y. A glycine-arginine domain in control of the human MRE11 DNA repair protein. Mol. Cell Biol. 2008, 28, 3058-3069. [CrossRef]

161. Boisvert, F.M.; Dery, U.; Masson, J.Y.; Richard, S. Arginine methylation of MRE11 by PRMT1 is required for DNA damage checkpoint control. Genes Dev. 2005, 19, 671-676. [CrossRef] [PubMed]

162. Yu, Z.; Vogel, G.; Coulombe, Y.; Dubeau, D.; Spehalski, E.; Hebert, J.; Ferguson, D.O.; Masson, J.Y.; Richard, S. The MRE11 GAR motif regulates DNA double-strand break processing and ATR activation. Cell Res. 2012, 22, 305-320. [CrossRef] [PubMed]

163. Yu, Z.; Chen, T.; Hebert, J.; Li, E.; Richard, S. A mouse PRMT1 null allele defines an essential role for arginine methylation in genome maintenance and cell proliferation. Mol. Cell Biol. 2009, 29, 2982-2996. [CrossRef] [PubMed]

164. Boisvert, F.M.; Rhie, A.; Richard, S.; Doherty, A.J. The GAR motif of 53BP1 is arginine methylated by PRMT1 and is necessary for 53BP1 DNA binding activity. Cell Cycle 2005, 4, 1834-1841. [CrossRef] [PubMed]

165. Adams, M.M.; Wang, B.; Xia, Z.; Morales, J.C.; Lu, X.; Donehower, L.A.; Bochar, D.A.; Elledge, S.J.; Carpenter, P.B. 53BP1 oligomerization is independent of its methylation by PRMT1. Cell Cycle 2005, 4, 1854-1861. [CrossRef]

166. Guendel, I.; Carpio, L.; Pedati, C.; Schwartz, A.; Teal, C.; Kashanchi, F.; Kehn-Hall, K. Methylation of the tumor suppressor protein, BRCA1, influences its transcriptional cofactor function. PLoS ONE 2010, 5, e11379. [CrossRef]

167. El-Andaloussi, N.; Valovka, T.; Toueille, M.; Hassa, P.O.; Gehrig, P.; Covic, M.; Hubscher, U.; Hottiger, M.O. Methylation of DNA polymerase beta by protein arginine methyltransferase 1 regulates its binding to proliferating cell nuclear antigen. FASEB J. 2007, 21, 26-34. [CrossRef]

168. El-Andaloussi, N.; Valovka, T.; Toueille, M.; Steinacher, R.; Focke, F.; Gehrig, P.; Covic, M.; Hassa, P.O.; Schar, P.; Hubscher, U.; et al. Arginine methylation regulates DNA polymerase beta. Mol. Cell 2006, 22, 51-62. [CrossRef]

169. Hu, D.; Gur, M.; Zhou, Z.; Gamper, A.; Hung, M.C.; Fujita, N.; Lan, L.; Bahar, I.; Wan, Y. Interplay between arginine methylation and ubiquitylation regulates KLF4-mediated genome stability and carcinogenesis. Nat. Commun. 2015, 6, 8419. [CrossRef]

170. Jansson, M.; Durant, S.T.; Cho, E.C.; Sheahan, S.; Edelmann, M.; Kessler, B.; La Thangue, N.B. Arginine methylation regulates the p53 response. Nat. Cell Biol. 2008, 10, 1431-1439. [CrossRef]

171. Scoumanne, A.; Zhang, J.; Chen, X. PRMT5 is required for cell-cycle progression and p53 tumor suppressor function. Nucleic Acids Res. 2009, 37, 4965-4976. [CrossRef] [PubMed]

172. Guo, Z.; Zheng, L.; Xu, H.; Dai, H.; Zhou, M.; Pascua, M.R.; Chen, Q.M.; Shen, B. Methylation of FEN1 suppresses nearby phosphorylation and facilitates PCNA binding. Nat. Chem. Biol. 2010, 6, 766-773. [CrossRef] [PubMed]

173. Qiu, J.; Li, X.; Frank, G.; Shen, B. Cell cycle-dependent and DNA damage-inducible nuclear localization of FEN-1 nuclease is consistent with its dual functions in DNA replication and repair. J. Biol. Chem. 2001, 276, 4901-4908. [CrossRef] [PubMed] 
174. Zheng, L.; Zhou, M.; Chai, Q.; Parrish, J.; Xue, D.; Patrick, S.M.; Turchi, J.J.; Yannone, S.M.; Chen, D.; Shen, B. Novel function of the flap endonuclease 1 complex in processing stalled DNA replication forks. EMBO Rep. 2005, 6, 83-89. [CrossRef] [PubMed]

175. Hamard, P.J.; Santiago, G.E.; Liu, F.; Karl, D.L.; Martinez, C.; Man, N.; Mookhtiar, A.K.; Duffort, S.; Greenblatt, S.; Verdun, R.E.; et al. PRMT5 Regulates DNA Repair by Controlling the Alternative Splicing of Histone-Modifying Enzymes. Cell Rep. 2018, 24, 2643-2657. [CrossRef] [PubMed]

176. Wesche, J.; Kuhn, S.; Kessler, B.M.; Salton, M.; Wolf, A. Protein arginine methylation: A prominent modification and its demethylation. Cell Mol. Life Sci. 2017, 74, 3305-3315. [CrossRef]

177. Easwaran, H.; Tsai, H.C.; Baylin, S.B. Cancer epigenetics: Tumor heterogeneity, plasticity of stem-like states, and drug resistance. Mol. Cell 2014, 54, 716-727. [CrossRef]

178. Feinberg, A.P.; Ohlsson, R.; Henikoff, S. The epigenetic progenitor origin of human cancer. Nat. Rev. Genet. 2006, 7, 21-33. [CrossRef]

179. Qiu, T.; Zhou, L.; Zhu, W.; Wang, T.; Wang, J.; Shu, Y.; Liu, P. Effects of treatment with histone deacetylase inhibitors in solid tumors: A review based on 30 clinical trials. Future Oncol. 2013, 9, 255-269. [CrossRef]

180. Morel, D.; Almouzni, G.; Soria, J.C.; Postel-Vinay, S. Targeting chromatin defects in selected solid tumors based on oncogene addiction, synthetic lethality and epigenetic antagonism. Ann. Oncol. 2017, 28, 254-269. [CrossRef]

181. Klinakis, A.; Karagiannis, D.; Rampias, T. Targeting DNA repair in cancer: Current state and novel approaches. Cell Mol. Life Sci. 2020, 77, 677-703. [CrossRef] [PubMed]

182. Candelaria, M.; Gallardo-Rincon, D.; Arce, C.; Cetina, L.; Aguilar-Ponce, J.L.; Arrieta, O.; Gonzalez-Fierro, A.; Chavez-Blanco, A.; de la Cruz-Hernandez, E.; Camargo, M.F.; et al. A phase II study of epigenetic therapy with hydralazine and magnesium valproate to overcome chemotherapy resistance in refractory solid tumors. Ann. Oncol. 2007, 18, 1529-1538. [CrossRef] [PubMed]

183. Zhang, Y.W.; Zheng, Y.; Wang, J.Z.; Lu, X.X.; Wang, Z.; Chen, L.B.; Guan, X.X.; Tong, J.D. Integrated analysis of DNA methylation and mRNA expression profiling reveals candidate genes associated with cisplatin resistance in non-small cell lung cancer. Epigenetics 2014, 9, 896-909. [CrossRef]

184. Verigos, J.; Karakaidos, P.; Kordias, D.; Papoudou-Bai, A.; Evangelou, Z.; Harissis, H.V.; Klinakis, A.; Magklara, A. The Histone Demethylase LSD1/KDM1A Mediates Chemoresistance in Breast Cancer via Regulation of a Stem Cell Program. Cancers 2019, 11, 1585. [CrossRef]

185. Glasspool, R.M.; Brown, R.; Gore, M.E.; Rustin, G.J.; McNeish, I.A.; Wilson, R.H.; Pledge, S.; Paul, J.; Mackean, M.; Hall, G.D.; et al. A randomised, phase II trial of the DNA-hypomethylating agent 5-aza-2'-deoxycytidine (decitabine) in combination with carboplatin vs carboplatin alone in patients with recurrent, partially platinum-sensitive ovarian cancer. Br. J. Cancer. 2014, 110, 1923-1929. [CrossRef]

186. Matei, D.; Fang, F.; Shen, C.; Schilder, J.; Arnold, A.; Zeng, Y.; Berry, W.A.; Huang, T.; Nephew, K.P. Epigenetic resensitization to platinum in ovarian cancer. Cancer Res. 2012, 72, 2197-2205. [CrossRef]

187. Fillmore, C.M.; Xu, C.; Desai, P.T.; Berry, J.M.; Rowbotham, S.P.; Lin, Y.J.; Zhang, H.; Marquez, V.E.; Hammerman, P.S.; Wong, K.K.; et al. EZH2 inhibition sensitizes BRG1 and EGFR mutant lung tumours to TopoII inhibitors. Nature 2015, 520, 239-242. [CrossRef] [PubMed]

188. Camphausen, K.; Tofilon, P.J. Inhibition of histone deacetylation: A strategy for tumor radiosensitization. J. Clin. Oncol. 2007, 25, 4051-4056. [CrossRef] [PubMed]

189. Zhang, Y.; Carr, T.; Dimtchev, A.; Zaer, N.; Dritschilo, A.; Jung, M. Attenuated DNA damage repair by trichostatin A through BRCA1 suppression. Radiat. Res. 2007, 168, 115-124. [CrossRef]

190. Wang, J.; Wang, Y.; Mei, H.; Yin, Z.; Geng, Y.; Zhang, T.; Wu, G.; Lin, Z. The BET bromodomain inhibitor JQ1 radiosensitizes non-small cell lung cancer cells by upregulating p21. Cancer Lett. 2017, 391, 141-151. [CrossRef]

191. Wu, C.; Jin, X.; Yang, J.; Yang, Y.; He, Y.; Ding, L.; Pan, Y.; Chen, S.; Jiang, J.; Huang, H. Inhibition of EZH2 by chemo- and radiotherapy agents and small molecule inhibitors induces cell death in castration-resistant prostate cancer. Oncotarget 2016, 7, 3440-3452. [CrossRef] [PubMed]

192. Xia, H.; Yu, C.H.; Zhang, Y.; Yu, J.; Li, J.; Zhang, W.; Zhang, B.; Li, Y.; Guo, N. EZH2 silencing with RNAi enhances irradiation-induced inhibition of human lung cancer growth in vitro and in vivo. Oncol. Lett. 2012, 4, 135-140. [CrossRef] [PubMed]

193. Zhu, X.; Wang, Y.; Tan, L.; Fu, X. The pivotal role of DNA methylation in the radio-sensitivity of tumor radiotherapy. Cancer Med. 2018, 7, 3812-3819. [CrossRef] [PubMed] 
194. Adimoolam, S.; Sirisawad, M.; Chen, J.; Thiemann, P.; Ford, J.M.; Buggy, J.J. HDAC inhibitor PCI-24781 decreases RAD51 expression and inhibits homologous recombination. Proc. Natl. Acad. Sci. USA 2007, 104, 19482-19487. [CrossRef] [PubMed]

195. Lee, J.H.; Choy, M.L.; Ngo, L.; Foster, S.S.; Marks, P.A. Histone deacetylase inhibitor induces DNA damage, which normal but not transformed cells can repair. Proc. Natl. Acad. Sci. USA 2010, 107, 14639-14644. [CrossRef] [PubMed]

196. Ha, K.; Fiskus, W.; Choi, D.S.; Bhaskara, S.; Cerchietti, L.; Devaraj, S.G.; Shah, B.; Sharma, S.; Chang, J.C.; Melnick, A.M.; et al. Histone deacetylase inhibitor treatment induces 'BRCAness' and synergistic lethality with PARP inhibitor and cisplatin against human triple negative breast cancer cells. Oncotarget 2014, 5, 5637-5650. [CrossRef]

197. Konstantinopoulos, P.A.; Wilson, A.J.; Saskowski, J.; Wass, E.; Khabele, D. Suberoylanilide hydroxamic acid (SAHA) enhances olaparib activity by targeting homologous recombination DNA repair in ovarian cancer. Gynecol. Oncol. 2014, 133, 599-606. [CrossRef]

198. Marijon, H.; Lee, D.H.; Ding, L.; Sun, H.; Gery, S.; de Gramont, A.; Koeffler, H.P. Co-targeting poly(ADP-ribose) polymerase (PARP) and histone deacetylase (HDAC) in triple-negative breast cancer: Higher synergism in BRCA mutated cells. Biomed. Pharmacother. 2018, 99, 543-551. [CrossRef]

199. Yin, L.; Liu, Y.; Peng, Y.; Peng, Y.; Yu, X.; Gao, Y.; Yuan, B.; Zhu, Q.; Cao, T.; He, L.; et al. PARP inhibitor veliparib and HDAC inhibitor SAHA synergistically co-target the UHRF1/BRCA1 DNA damage repair complex in prostate cancer cells. J. Exp. Clin. Cancer Res. 2018, 37, 153. [CrossRef]

200. Yang, L.; Zhang, Y.; Shan, W.; Hu, Z.; Yuan, J.; Pi, J.; Wang, Y.; Fan, L.; Tang, Z.; Li, C.; et al. Repression of BET activity sensitizes homologous recombination-proficient cancers to PARP inhibition. Sci. Transl. Med. 2017, 9, eaal1645. [CrossRef]

201. Karakashev, S.; Zhu, H.; Yokoyama, Y.; Zhao, B.; Fatkhutdinov, N.; Kossenkov, A.V.; Wilson, A.J.; Simpkins, F.; Speicher, D.; Khabele, D.; et al. BET Bromodomain Inhibition Synergizes with PARP Inhibitor in Epithelial Ovarian Cancer. Cell Rep. 2017, 21, 3398-3405. [CrossRef] [PubMed]

202. Sun, C.; Yin, J.; Fang, Y.; Chen, J.; Jeong, K.J.; Chen, X.; Vellano, C.P.; Ju, Z.; Zhao, W.; Zhang, D.; et al. BRD4 Inhibition Is Synthetic Lethal with PARP Inhibitors through the Induction of Homologous Recombination Deficiency. Cancer Cell. 2018, 33, 401-416. [CrossRef] [PubMed]

203. Wilson, A.J.; Stubbs, M.; Liu, P.; Ruggeri, B.; Khabele, D. The BET inhibitor INCB054329 reduces homologous recombination efficiency and augments PARP inhibitor activity in ovarian cancer. Gynecol. Oncol. 2018, 149, 575-584. [CrossRef] [PubMed]

204. Muvarak, N.E.; Chowdhury, K.; Xia, L.; Robert, C.; Choi, E.Y.; Cai, Y.; Bellani, M.; Zou, Y.; Singh, Z.N.; Duong, V.H.; et al. Enhancing the Cytotoxic Effects of PARP Inhibitors with DNA Demethylating Agents-A Potential Therapy for Cancer. Cancer Cell. 2016, 30, 637-650. [CrossRef] [PubMed]

205. Berry, W.L.; Janknecht, R. KDM4/JMJD2 histone demethylases: Epigenetic regulators in cancer cells. Cancer Res. 2013, 73, 2936-2942. [CrossRef]

206. Lee, D.H.; Kim, G.W.; Jeon, Y.H.; Yoo, J.; Lee, S.W.; Kwon, S.H. Advances in histone demethylase KDM4 as cancer therapeutic targets. FASEB J. 2020, 34, 3461-3484. [CrossRef]

207. Fontebasso, A.M.; Schwartzentruber, J.; Khuong-Quang, D.A.; Liu, X.Y.; Sturm, D.; Korshunov, A.; Jones, D.T.; Witt, H.; Kool, M.; Albrecht, S.; et al. Mutations in SETD2 and genes affecting histone H3K36 methylation target hemispheric high-grade gliomas. Acta Neuropathol. 2013, 125, 659-669. [CrossRef]

208. Ho, T.H.; Kapur, P.; Joseph, R.W.; Serie, D.J.; Eckel-Passow, J.E.; Tong, P.; Wang, J.; Castle, E.P.; Stanton, M.L.; Cheville, J.C.; et al. Loss of histone H3 lysine 36 trimethylation is associated with an increased risk of renal cell carcinoma-specific death. Mod. Pathol. 2016, 29, 34-42. [CrossRef]

209. Sun, Z.; Zhang, Y.; Jia, J.; Fang, Y.; Tang, Y.; Wu, H.; Fang, D. H3K36me3, message from chromatin to DNA damage repair. Cell Biosci. 2020, 10, 9. [CrossRef]

210. Pfister, S.X.; Markkanen, E.; Jiang, Y.; Sarkar, S.; Woodcock, M.; Orlando, G.; Mavrommati, I.; Pai, C.C.; Zalmas, L.P.; Drobnitzky, N.; et al. Inhibiting WEE1 Selectively Kills Histone H3K36me3-Deficient Cancers by dNTP Starvation. Cancer Cell. 2015, 28, 557-568. [CrossRef]

211. Ashizawa, M.; Saito, M.; Min, A.K.T.; Ujiie, D.; Saito, K.; Sato, T.; Kikuchi, T.; Okayama, H.; Fujita, S.; Endo, H.; et al. Prognostic role of ARID1A negative expression in gastric cancer. Sci. Rep. 2019, 9, 6769. [CrossRef] [PubMed] 
212. Kadoch, C.; Hargreaves, D.C.; Hodges, C.; Elias, L.; Ho, L.; Ranish, J.; Crabtree, G.R. Proteomic and bioinformatic analysis of mammalian SWI/SNF complexes identifies extensive roles in human malignancy. Nat. Genet. 2013, 45, 592-601. [CrossRef] [PubMed]

213. Shen, J.; Peng, Y.; Wei, L.; Zhang, W.; Yang, L.; Lan, L.; Kapoor, P.; Ju, Z.; Mo, Q.; Shih Ie, M.; et al. ARID1A Deficiency Impairs the DNA Damage Checkpoint and Sensitizes Cells to PARP Inhibitors. Cancer Discov. 2015, 5, 752-767. [CrossRef] [PubMed]

214. Williamson, C.T.; Miller, R.; Pemberton, H.N.; Jones, S.E.; Campbell, J.; Konde, A.; Badham, N.; Rafiq, R.; Brough, R.; Gulati, A.; et al. ATR inhibitors as a synthetic lethal therapy for tumours deficient in ARID1A. Nat. Commun. 2016, 7, 13837. [CrossRef]

(C) 2020 by the authors. Licensee MDPI, Basel, Switzerland. This article is an open access article distributed under the terms and conditions of the Creative Commons Attribution (CC BY) license (http://creativecommons.org/licenses/by/4.0/). 